\title{
The Effect of Supply Chain Power on Bank Financing*
}

\author{
Mohammad M. Rahaman \\ Saint Mary's University \\ Mohammad . Rahaman@SMU . ca \\ (+1) $902-420-5730$
}

\author{
P. Raghavendra Rau \\ University of Cambridge \\ r.rau@jbs.cam.ac.uk \\ +44（0) 1223761079
}

\author{
Ashraf Al Zaman \\ Saint Mary's University \\ Ashraf .Zaman@SMU . ca \\ (+1) $902-491-6272$
}

December 2019

\begin{abstract}
Using comprehensive bank-loan contract information, we show that the power of a firm relative to its suppliers eases its terms of bank financing, specifically through lower loan prices and less restrictive non-price contract terms. Our results are robust to controlling for product-market competition. Supply chain power enables the firm to achieve a greater level of control over its inventory, constituting a significant portion of the reduction in its overall loan cost. We argue that it is important to consider supply-chain related issues when analyzing the external-financing capacity of firms.
\end{abstract}

KEYWORDS: Supply Chain; Cost of Debt; Bank financing; Product-market Competitiveness; Inventory Control

JEL Classification: G00, G21, G30, G32, L14, L23

\footnotetext{
${ }^{*}$ Corresponding author: P. Raghavendra Rau, University of Cambridge; Email: r.rau@jbs . cam . ac. uk; Phone: +44 (0) 1223761079. We thank an anonymous referee, Varouj Aivazian, Carol Alexander (editor), Gimmy Dett, Alan Jagolinzer, Subhankar Nayak, Jiaping Qiu, Mehrnoush Shahhosseini, and participants at the 2017 Northern Finance Association Meetings, and the 2014 Financial Management Association Meetings for helpful comments and suggestions. We also thank Michael Roberts for sharing his matching file for the DealScan and the Compustat databases. Mohammad Rahaman is especially thankful to the Social Sciences and Humanities Research Council (SSHRC) of Canada for a research grant.
} 


\section{INTRODUCTION}

How does a firm's interactions with its suppliers affect its ability to access financing? In this paper, we use granular firm-level bank loan data to investigate how a firm's power over its suppliers affects the loan terms it receives in the bank-loan market. We show that supply chain power eases the terms of the firm's bank financing, both lowering its loan costs and easing restrictions imposed by non-price contract terms. This relationship holds after controlling for product-market competition, and does not depend on the type of supply chain, though we find that creditors value arm's-length supply chains more favorably than relationship-specific supply chains.

Supply chain management (SCM) has become an increasingly important concern for firms in the past few years. Articles in the popular press argue that firms around the world have been forced to restructure their supply chains following significant political events such as Brexit, the renegotiation of international trade treaties, predominantly by the United States (US), or the threat of tariff wars between China and the US. Many of these articles also describe a concomitant drop in the intensity of cross-border financial links such as cross-border loans. ${ }^{1}$

However, despite its growing importance, the finance and accounting literature has only recently begun devoting attention to examining how a firm's economic links with its suppliers influences its financial policies. Examples include Boissay and Gropp (2013) who show how credit-constrained firms that face liquidity shocks pass on a significant proportion of these shocks to their suppliers. Hertzel, Li, Officer, and Rodgers (2008) document how firm distress related to bankruptcy filings is associated with significant negative stock price effects for suppliers. Moon and Phillips (2017) show that firms with more outside-purchase contracts, including those related to input supply and outsourcing, are less likely to use financial leverage, thereby reducing the firm's and its contracting parties' expected cost of financial distress. Lian (2017) shows that a supplier's likelihood of financial distress is positively related to its major customer's financial distress status. Surprisingly little research has been done on whether the power firms hold over their suppliers affects the terms on which they are able to access external financing in the first place. ${ }^{2}$

\footnotetext{
${ }^{1}$ See, for example, "The global list", The Economist, Briefing Section, January 26, 2019. The Economist describes the drop in global integration as slowbalisation. It also discusses a decline in the volume of cross-border loans accompanying the drop in cross-border links.

${ }^{2}$ In contrast, a considerable amount of research has been carried out on the influence of product-market structure on firm policy (see for
} 
This is an important issue. Firms interact both with customers (through product markets) and with suppliers. Firms usually face little choice in their customer base relative to their supplier base. Hence, since product-market competition is more likely to be exogenous to the firm, prior research has typically examined the effect of product-market competition on the firm in isolation. However, this focus also has the potential of leading to biased conclusions. Valta (2012), for example, shows that the cost of bank debt is systematically higher for firms that operate in competitive product markets and that banks price financial contracts after taking these competitive threats into account. However, if the firm is a monopsony with considerable power over its suppliers, it may pass some of the effects of product-market competition up the supply chain. If banks recognize this ability, they should likewise price supply chain interactions into their contracts. Similarly, Houston, Lin, and Zhu (2016) show that a firm's financial distress significantly elevates the financing costs of its suppliers. However, if a supplier has several major customers and can switch among them easily, an individual customer's financial distress should have little or no impact on the financing capacity of the supplier. Bernard (2016) shows that financially constrained firms avoid financial statement disclosure to mitigate predation risk originating from a competitive product market. If, however, the supply chain power of a firm can alleviate its external financing constraints, a distressed firm does not necessarily have to rely on modifying its disclosure practices to address the risk of product-market predation. Finally, while a number of authors have shown that the presence of excess inventory hurts the financial and operating performance of firms (Sloan, 1996; Thomas and Zhang, 2002; Belo and Lin, 2012), supply chain power might enable a firm to reduce its inventory. ${ }^{3}$

It is unclear, however, that the cost of external financing will always decline when the firm's supply chain power increases. For example, consider the choice of supplier the firm uses to source its inputs. Deming (1986) suggests that a long-term, tightly integrated relationship with a single source improves quality and lowers total costs. However, Rogerson (1992) argues that Deming's approach may lead to a "hold-up" situation if contracts are incomplete. In more extreme cases, strong coalitions of input providers may increase the bargaining power

example, Costello, 2013, 2017; Hui, Klasa, and Yeung, 2012; Hennessy and Livdan, 2009; Chu, 2012; Kale and Shahrur, 2007; Banerjee, Dasgupta, and Kim, 2008; Campello and Gao, 2017; Houston et al., 2016). In particular, researchers have examined how the product-market structure of firms influences its financial statement disclosures (Bernard, 2016), its cash holdings (Morellec, Nikolov, and Zucchi, 2013), its cost of equity (Hou and Robinson, 2006; Hoberg and Phillips, 2010), the quantity of debt (MacKay and Phillips, 2005; Xu, 2012), and the pricing of its debt (Valta, 2012).

${ }^{3}$ For example, in describing Honda's inventory management system in the UK, Barker and Campbell (2018) note that orders from EU suppliers arrive within 5 hours while others, such as customized car seats, arrive from local suppliers within 75 minutes before use. 
of suppliers relative to the firm (Nagarajan and Bassok, 2008; Nagarajan and Sosic, 2009), extracting a larger surplus from the firm. Unforeseen supply-chain disruptions due to natural and man-made disasters can also have detrimental impacts on firm profitability (Hendricks and Singhal, 2005). In contrast to Deming, therefore, Porter (1985) suggests that the best way to assure the firm low prices, high quality, and the lowest total cost is to have multiple sources and competing suppliers. Hence, supply chain power may affect the likelihood of financial distress and the cost of external financing in different ways. Tightly integrated suppliers allow firms to control quality and allow flexible contracting opportunities, reducing default risk, but expose the firm to supply chain related hold-up issues or supply disruptions, increasing default risk. A relatively competitive suppliers' market allows firms to manage themselves more effectively during uncertain economic environments even if they do not have supply chain power, lowering the possibility of financial distress.

Similarly, the extent to which a firm makes relationship-specific investments in its supply chain can also affect the liquidity of the firm's assets and, in turn, a financier's potential losses, should default occur. Reliance on a supply chain that requires relationship-specific investment may decrease the market liquidity of a firm's assets because these assets may have little value outside the relationship. However, relationship-specific investment in the supply chain can lead to lower leverage and greater bargaining power for firms, thereby lowering the risk of default and liquidation (Titman, 1984; Maksimovic and Titman, 1991).

In our paper, we first develop several measures of a firm's supply chain power. We use the number of suppliers in the firm's supply chain to capture the density of its supply chain. We use the extent of dispersion in the dollar amounts of inputs sourced from different suppliers to measure the degree to which a firm relies on heterogeneous input sources for its productive operation. To measure the ability of a firm to extract more surplus from its supply chain, thereby giving it a greater incentive to rely on the chain, we use a modified version of a Lerner's index. In each case, increasing values of these measures imply a greater power for the firm relative to the suppliers on its supply chain. Finally, we combine all the above measures into a single index of supply chain power by extracting the first component from a Principal Component Analysis. There are significant variations between firms in our sample within a 2-digit SIC industry in terms of their supply chain power. 
In a univariate analysis, we first find that a greater degree of supply chain power is associated with a larger amount of debt, a lower spread, a longer maturity, lower collateral, fewer covenants, and a higher likelihood of syndication and relationship-based transactions. A high level of supply chain power appears to be associated with reduced credit risk, leading to more favorable price and non-price loan-contract terms. Controlling for the level of product-market competition, various firm, loan, and unobserved industry- and time-invariant attributes, a conditional OLS regression analysis supports these conclusions. To get a sense of the economic magnitude of our results, based on our OLS estimates, a one-standard-deviation increase in the supply chain power index measure is associated with a 20.67 basis point reduction in the loan spread, translating into yearly savings of \$0.1958 million for an average sample loan size of $\$ 94.74$ million. Assuming that a sample firm has a long-term AAA credit rating, the total compounded debt-service savings accumulate to $\$ 1.1278$ million for a loan maturing in 5 years. We measure how the effect of product-market power on the cost of debt changes if we were to ignore the supplier-side interactions of firms, and document that prior studies on productmarket power and the cost of debt mis-estimate the external debt financing benefit of product market power. We also show that the negative relationship between power and credit risk holds irrespective of the type of supply chain, though creditors appear to value arm's-length supply chains more favorably than relationship-specific supply chains. Finally, using mediation analysis, we show that supply chain power reduces inventory-related risk for firms.

Our results are robust to a number of checks. First, to show that our results are not simply due to supply chain power being a proxy for profitability, we run a number of additional analyses, explicitly controlling for profitability. In every case, we show that supply chain power remains significant. Next, to show causality and address concerns of endogeneity and omitted variable bias, we deploy an instrumental variable analysis and analyze a quasi-natural experiment. Both support a causal (negative) interpretation of the relationship between supply chain power and the overall cost of bank loans. Furthermore, we show that the intuition conveyed by our main findings extend naturally to traditional measures of bankruptcy risk in the literature in the sense that supply chain power is negatively associated with the bankruptcy risk of firms. Finally, we show that our core findings in the OLS framework remain robust to how the firm sources inputs (the nature of its supply chain - arm's-length versus relationship-specific) and to any simultaneity biases between the price and non-price loan-contract terms. 
Overall, our paper adds to the accounting and finance literature in three ways. First, we provide a comprehensive analysis of how a firm's economic links with its suppliers affect its provisions for bank debt financing. The importance of these supply chain relationships, in particular, has grown significantly in recent times to such an extent that disruptions in supplychain linkages can, on average, wipe out 7\% of a firm's equity value (World Economic Forum, 2013). In the presence of significant political events such as Brexit or tariff wars, the potential for these disruptions increases. Furthermore, the magnitude of the multi-billion dollar supplychain disruptions insurance market (Forbes, 2015) appears to imply that supply-chain related interactions are of paramount importance to industry practitioners. ${ }^{4}$ While the insurance literature has been at the forefront of pricing supply-chain related risk (Dong and Tomlin, 2012), the accounting and finance literature so far has been relatively silent on this issue. Our paper fills this void by assessing the impact of supply-chain interactions on firm-level credit risk.

Second, we provide a comprehensive analysis on how supply chain power affects a firm's debt financing from the perspective of a particular specialized debtholder, a bank. Most prior literature examines the nexus between supply chain attributes and overall firm financial conditions. For example, Costello (2013) shows that financial covenants can substitute for costly monitoring in supply contracts and, therefore, can reduce informational and incentive problems in supply chain relationships. Hui et al. (2012) show that a firm's bargaining power relative to its suppliers significantly determines how quickly the firm recognizes losses suggesting that supply chain interactions of a firm influence its accounting practices, specifically, its accounting conservatism. Hennessey and Livdan (2009) show theoretically that leverage increases with supplier bargaining power (e.g., unionization rates) and decreases with utilization of non-verifiable inputs (e.g., human capital). Chu (2012) models the relationship between firm leverage and supplier market structure and argues that firm leverage decreases with the degree of competition between suppliers. Kale and Shahrur (2007) show that leverage is negatively associated with the R\&D intensities of the firm's customers and suppliers. Banerjee et al. (2008) find that firms in bilateral relationships with suppliers and customers are likely to have lower debt ratios. Moon and Phillips (2017) show that firms with more

\footnotetext{
${ }^{4}$ Supply-chain disruption insurance protects against interruptions in the supply chain. For example, a fire at a sub-supplier's facility of Ericsson on March 18, 2000 led to a reduction in the supply of radio-frequency chips. Ericsson's business interruption costs as a result of this incident were calculated to be approximately $\$ 200$ million, which was reimbursed by insurance companies (Norrman and Jansson, 2004). In a survey of 600 executives, Deloitte Consulting LLP (2013) determined that nearly $75 \%$ of the executives identify supply-chain risk to be extremely or very important in their strategic decision-making.
} 
outside purchase contracts use less financial leverage and, as a result, have lower risk of financial distress. Houston et al. (2016) and Kolay, Lemmon, and Tashjian (2015) show that the financial distress of a supplier reverberates down the supply chain, ultimately increasing financing costs of downstream firms. However, banks are more specialized than public debt markets, in that they provide expert monitoring (Diamond, 1984) and have inside knowledge of firms' financial health (Billett, Flannery, and Garfinkel, 2006; Campbell and Kracaw, 1980; Gande and Saunders, 2012). Hence the above results may not be applicable to bank financing. In our paper, we complement the extant research by providing granular-level evidence, using comprehensive bank-loan information, that supply chain power favorably affects specific bank contracting terms. Specifically, Costello (2018) shows that suppliers exposed to a contraction in bank lending shrink the supply of trade credit offered to their buyers. Our paper complements this result by showing that firms with supply chain power are offered better terms in the bank loan market to begin with. Our results also complement those of Patatoukas (2012) and Krishnan, Patatoukas, and Wang (2018) who show that customer-base concentration has positive effects on firm performance and negative effects on audit fees, respectively.

Finally, the extant literature typically analyses a firm's interactions with either its suppliers or customers in isolation. We explicitly take into account the interdependencies between a firm's supply-side and demand-side interactions. By highlighting how supply chain power alleviates the external financing constraints of firms, our findings also have the potential to shed light on why some firms are financially constrained while others are not.

The rest of the paper is organized as follows. Section 2 describes the data and main variables. Section 3 presents a conditional regression analysis followed by various identification and robustness tests. Section 4 shows how supply chain power affects the relationship between inventory control efficiency, a factor identified in the prior literature, and the overall cost of bank loans. Section 5 concludes. 


\section{Data AND VARiables}

\subsection{DATA}

To construct our sample, we combine three separate databases. First, we obtain bank loan information from the DealScan database of the Loan Pricing Corporation (LPC), which contains detailed information on US and foreign commercial loans made to corporations since 1989. The database was originally constructed from Security and Exchange Commission (SEC) corporate financial filings and through direct research from banks. In our empirical analysis, the basic unit is a loan, also referred to as a facility or tranche in DealScan. Second, we construct firm-level supply-chain power measures by collecting information on a firm's suppliers from the Compustat customer-segment database. Finally, we merge the DealScan loan-level data and the firm-level customer-segment data with firm-level financial information from Compustat annual files. ${ }^{5}$ Our final sample consists of 10,926 loans over the period 1990-2012. ${ }^{6}$

Our database contains granular loan-level information about customers representing more than $10 \%$ of sales for each supplier. Clearly, from a supplier's perspective, such customersupplier relationships are economically important. However, the same may not be true from the customer's perspective, because suppliers' sales to the customer may be an insignificant percentage of the customer's overall cost of goods sold (COGS). To dispel this concern, we perform additional analyses to show that such customer-supplier relationships are also economically important from customers' perspectives. $^{7}$

The distribution of sample loans over the sample periods is shown in panel A of Table 1 . Since firms generally do not initiate loans every year, the number of firms that we observe in our sample varies over the sample period. Panel B of Table 1 describes various loan types. Among the sample loans, the three primary types are revolving credit facilities $(5,115 ; 47 \%)$, term loans $(2,268 ; 21 \%)$, and 364-day facilities $(843 ; 17 \%)$. Panel B also shows various loan purposes. The primary purposes for our sample loans, as described in DealScan, are: corporate purposes (42\%), debt repayment (14\%), working capital financing (12\%), and commercial paper backup (12\%). Our sample loan features are similar to that of Bharath, Dahiya, Saunders,

\footnotetext{
${ }^{5}$ We thank Michael Roberts for providing us with the link file.

${ }^{6}$ We stop in 2012 because at the time of writing, the link file was only available to this date. We exclude all financial firms from our sample.

${ }^{7}$ We report these analyses in the online appendix for the sake of brevity.
} 
and Srinivasan (2011) and Aivazian, Qiu, and Rahaman (2015).

Table 1 is about here

\subsection{MAIN VARIABLES}

\subsubsection{LoAn Contract Terms}

The primary loan-contract term of our analysis is the cost of the loan denoted as $S P R E A D_{\text {lijt }}$, where $l$ stands for loan, $i$ indexes firm, $j$ indexes industry, and $t$ refers to the loan initiation year. Much of the literature on the cost of bank debt (e.g., Bharath et al., 2011; Drucker and Puri, 2005; Graham, Li, and Qiu, 2008) uses the loan spread over LIBOR at the time of the loan origination as a measure of the cost of bank debt. The "All-in-Drawn" variable in the DealScan database describes the amount the borrower pays in basis points over LIBOR for each dollar drawn down. It also adds any annual (or facility) fee paid to the bank group to the spread of the loan. We use the logarithm of the "All-in-Drawn" variable as the measure of the cost of bank debt in our analysis. A lower loan spread generally indicates a greater funding liquidity for firms. Berg, Saunders, and Steffen (2016) propose a new measure for the total cost of corporate borrowing (TCB) that accounts for fees and the fact that most loans are not immediately drawn down at origination. We examine whether our results are robust to this measure of the total cost of borrowing by constructing a similar cost of bank loan measure. We also examine other loan-contract terms such as loan amount (in millions of dollars), loan maturity (in months), loan security (indicator variable), and number of loan covenants.

\subsubsection{Supply Chain PoWer (SCP)}

Our primary explanatory variable is the power the firm has over the suppliers in its chain. Following the literature in customer-supplier relationships (Kale and Shahrur, 2007; Banerjee et al., 2008; Lee, 2010; Williams, 2012; Moon and Phillips, 2017; Campello and Gao, 2017), we use the Compustat customer-segment data set to construct three separate firm-level measures of supply chain power (SCP).

First, we use the number of suppliers in a firm's (denoted as $i$ ) supply chain in a given year (denoted as $t$ ). We match Compustat customer-segment data with our sample firms by company name and year and identify the number of different suppliers a firm has in a given 
year. We then calculate the measure $N U M S U P P_{i t}$ as: $\log (1+$ number of suppliers $)$. The measure captures the density of a firm's supply chain and we argue that a higher density of suppliers implies a greater power for the firm relative to its suppliers.

Our second measure is the dispersion of suppliers (SDISPERSION ${ }_{i t}$ ) within a firm's supply chain. To construct the measure, we first identify the dollar value (in million \$) of inputs sourced by a sample firm from each supplier in a given year. We then define SDISPERSION as follows:

$$
\text { SDISPERSION }_{i t}=1-\sum_{s=1}^{N}\left(\frac{S U P P_{s t}}{\text { TOTALSUPP }_{i t}}\right)^{2}
$$

where $S U P P_{s t}$ is the dollar value of inputs sourced by firm $i$ from supplier $s$ in period $t$, TOTALSUPP $P_{i t}$ is the total dollar value of inputs sourced by firm $i$ in period $t$, and $N$ is the number of different suppliers in firm i's supply chain in period $t$. This construction is similar to the inverse of an input-based Herfindahl index and ranges between 0 and 1 . A higher value

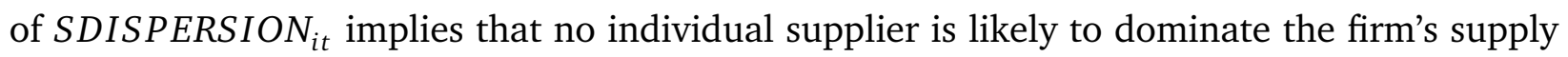
chain and hence increases the power of the firm relative to its suppliers.

Our third measure is an index of market power of a firm over its suppliers (SPOWER $\left.R_{i t}\right)$ within its supply chain. To capture the cross-supplier differences in market power, we use the Lerner index of a supplier (Lerner, 1934), defined as: $\frac{P-M C}{P}$, where $P$ is a supplier's product price and $M C$ is the marginal cost of production. The Lerner index directly measures the ability of a supplier to charge a price above its marginal cost. We follow Gaspar and Massa (2006) and define the Lerner index as operating profits (before depreciation, interest, special items, and taxes) over sales using Compustat data items. We then define our SPOWER $R_{i t}$ proxy as follows:

$$
S P O W E R_{i t}=1-\sum_{s=1}^{N}\left(\frac{S U P P_{s t}}{T O T A L S U P P_{i t}} \times L I N D E X_{s t}\right)
$$

where $\frac{S U P P_{s t}}{T_{\text {SOTALSPP }}}$ is the fraction of input sourced from supplier $s$ by firm $i$ in period $t, L I N D E X_{s t}$ is the Lerner index of supplier $s$ in period $t$, and $N$ is the total number of suppliers firm $i$ has in its supply-chain in period $t$. Since $S P O W E R_{i t}$ ranges between 0 and 1 , we use a logarithmic transform of the measure as: $\log \left(1+S P O W E R_{i t}\right)$. A higher value of the measure implies a lower ability of the firm's suppliers to exert market power over the firm. Finally, we aggregate over all three measures by taking the first principal component from a Principal Component 
Analysis (PCA) to create a composite index of supply chain power of a firm. We find significant variations across firms and industries in our supply chain power measure. ${ }^{8}$ We report most of our analyses using this single index of supply chain power.

\subsubsection{Product-Market PoWer}

To assess the robustness of our analysis relative to the literature on the effect of productmarket power on the cost of debt, we also control for the effects of product-market power on the cost of bank debt while estimating the effect of supply chain market power on the cost of debt. Following Valta (2012), we use the fitted Herfindahl-Hirschman Index (HHI) of Hoberg and Phillips (2010) to capture a firm's product-market concentration. In theory, HHI is positively associated with the pricing power of a firm and hence should lower the firm's cost of external debt. As in Valta (2012), we construct an indicator variable based on the HHI index of Hoberg and Phillips (2010) to classify a firm's industry into competitive and non-competitive industries. Specifically, we define an industry as competitive if the fitted HHI is below the $25^{\text {th }}$ percentile of its sample distribution, otherwise it is defined as a non-competitive industry. In addition to the traditional product-market concentration measure, we follow Patatoukas (2012) in constructing a customer concentration measure from the Compustat customer segment database as follows: $\sum_{c=1}^{N}\left(\frac{\text { Sales }_{c i t}}{\sum_{c=1}^{N} \text { Sales }_{c i t}}\right)^{2}$, where Sales $_{\text {cit }}$ refers to sales to customer $c$ by supplier $i$ in period $t$ and $N$ is the total number of customers in period $t$.

\subsubsection{Firm-LeVel Controls}

We use the book value of total assets to control for firm size. Larger firms tend to have longer histories and be more established. Thus, the informational asymmetry between a large firm and its lenders is likely to be less severe, resulting in more favorable contract terms. Tobin's $q$, constructed following Duchin (2010), is used as a proxy for the firm's growth opportunities. It is plausible that growth firms may be more vulnerable to financial distress and to informational asymmetries. In our context, since we control for characteristics such as tangibility of book assets, growth opportunities may instead lower loan costs since they represent an additional value over book assets that debtholders can access in the event of default. Leverage, the ratio of the long-term debt to total assets, is used to control for the firm's existing debt level. Firms

\footnotetext{
${ }^{8}$ We report the sample distribution of the SCP measure and the list of firms that are in the top $1 \%$ and the bottom $1 \%$ of the sample distribution of the $S C P$ measure in the online appendix.
} 
with higher leverage ratios have, on average, higher default risk and are thus expected to have higher borrowing costs. We also include Profitability, defined as the ratio of EBIT to total assets, because default risk is lower for profitable firms, lowering borrowing costs. Asset tangibility, defined as the ratio of net plant, property, and equipment (PP\&E) to total assets, is included to control for the easier recoverability of tangible assets in the case of default. Finally, following Bharath and Shumway (2008), Current ratio, Interest coverage ratio, and the Expected default frequency, are included to further control for default risk and the extent of external financial constraints. A higher value of Interest coverage ratio indicates better financial health and lower default risk of debt. According to Whited (1992), Hu and Schiantarelli (1998), and Guariglia (2008), firms with higher interest coverage ratios have better access to external finance. A higher value of Expected default frequency indicates worse financial health and higher default risk of debt. We winsorize all firm-level variables at the $1 \%$ level.

\subsubsection{LOAN-LEVEl Controls}

Finally, we control for loan characteristics that are related to the price of debt. We use the facility amount (in \$ millions) to control for loan size. Loan size may reflect economies of scale in bank lending and is expected to be inversely related to the loan rate (see Berger and Udell, 1992). We use the maturity (in months) of the loan to control for liquidity. Longer-term debt tends to be charged a higher loan rate because of its lower liquidity. We control for the collateral structure of a loan by incorporating a dummy variable, collateral, indicating whether a loan is secured. ${ }^{9}$ We use a Big 3 lender dummy variable to control for whether the loan is syndicated by any of the three largest US banks (Aivazian et al., 2015). Bharath et al. (2011) show that around $70 \%$ of all syndicated loans are relationship-based, making this a systemic feature of the syndicated loan market. Therefore, we also control for whether a loan is relationship-based or arm's length. Following Bharath et al. (2011), we classify a loan as relationship-based if the issuing firm had a prior lending relationship with the lead bank in the syndicate within the five years to the current loan initiation year. We also include dummy variables for loan type and loan purpose. As shown in Table 1, loans are of different types, such as 364-day loans, term loans, and revolving loans, and are used for different purposes, such as for debt repayments, takeovers, and working-capital financing. They are usually associated with different risks, and

\footnotetext{
${ }^{9}$ In the DealScan data set, security features are missing for some loans. In such cases, we assume that the loan is not secured.
} 
tend to be priced differently.

\subsection{DESCRIPTIVE Statistics}

Table 1 documents differences in the time-series of loan issuance patterns as well as the differences in loan types and purposes between high and low SCP firms. We define a firm as having high supply-chain power if the firm-level $S C P$ measure is above the $75^{\text {th }}$ percentile of its sample distribution. Similarly, a firm is defined as having low power in its supply chain if the firm-level SCP measure is below the $25^{\text {th }}$ percentile of its sample distribution.

The table shows that high-SCP firms are more likely to utilize short-term 364-day facilities while low-SCP firms are more likely to use revolving credit maturing in more than a year. Under the Basel II international banking standards, if a loan facility met the 364-day facility criteria, then the undrawn portion of the facility at any time was treated as being off-balance sheet and was accorded a credit conversion factor of $0 \%$ to $20 \%$. Banks, therefore, typically deem issuers of 364-day facilities (high-SCP firms) less risky and typically offer more attractive undrawn fees (commitment and annual fees) on 364-day facilities than on multi-year revolvers.

Similarly, the table shows that high-SCP firms are twice as likely to use loan facilities for commercial paper back-up while low-SCP firms are twice as likely to use loan facilities for working capital management purposes. It is widely recognized that companies with less liquid assets and high sales seasonality rely on working capital loans to help with periods of reduced business activity. In contrast, companies with better credit ratings can issue commercial paper, while a backup line of credit effectively provides an alternative source of liquidity for the issuer. Given that the loan spread reflects not only a default premium determined by the firm's credit risk but also a liquidity premium (e.g., Longstaff, Mithal, and Neis, 2005; Chen, Lesmond, and Wei, 2007; He and Xiong, 2012; Brunnermeier and Pedersen, 2009), these differences in loan characteristics suggest that rollover risk and liquidity premia of high-SCP firms are likely to be lower than for low-SCP firms.

Table 2 shows various price and non-price loan contract terms and examines the unconditional mean difference between high- and low-SCP firms. To capture the difference between high- and low-SCP firms, we define $H M L$ as: HSCP - LSCP. Panel A of Table 2 shows that high-SCP firms obtain an unconditional loan spread that is 63.67 basis points lower than low- 
SCP firms. Furthermore, high-SCP firms also pay lower amounts of various fees associated with a loan contract and, as a result, their total cost of borrowing is, on average, 34.41 basis points lower than low-SCP firms. Panel B of the table shows unconditional mean differences in various non-price loan contract terms between high- and low-SCP firms. High-SCP firms, on average, raise greater amounts in loan financing, though with shorter loan maturities. They use less collateral, have fewer loan covenants, and have a higher likelihood of loan syndication. Moreover, loans to high-SCP firms are more likely to be relationship-based than arm's length. These descriptive statistics suggest that creditors explicitly take into account the costs and benefits arising from supply-chain power in the pricing and designing of loan contracts. Supply chain power appears to be negatively related to firm credit risk, and is manifested in more favorable price and non-price loan-contract terms.

Tables 2 and 3 are about here

Table 3 provides granular-level characterization of loan covenants and collateral structure for our sample firms and loans. ${ }^{10}$ Demiroglu and James (2010) show that loan covenants convey information concerning future changes in investment and financial policies of firms. Li, Vasvari, and Moerman (2016) argue that progressive tightness of (earning-based) covenants over time can be used as a signal by underperforming borrowers expecting future performance improvements. Beatty, Ramesh, and Weber (2002) find that borrowers are willing to pay substantially higher interest rates to retain accounting flexibility that may help them avoid covenant violations. Using a new measure of aggregate probability of covenant violation, Demerjian and Owens (2016) emphasize the importance of inclusion of accounting-based financial covenants in debt contracting.

Consistent with these studies, the summary statistics presented in the table suggest that creditors afford greater flexibility to high-SCP firms in terms of how they use their operating, investment, and financing cash flows compared to low-SCP firms, i.e., less stringent general covenants. Additionally, high-SCP firms enjoy less stringent leverage restrictions (maximum debt/equity financial covenant) than low-SCP firms. However, the flexibility in cash-flow us-

\footnotetext{
${ }^{10}$ Loan covenants in DealScan are generally classified into three categories, i.e., general, net worth, and financial covenants. The set of general covenants describes whether the borrower is restricted from paying dividends to its shareholders, the percentage of excess cash-flow and net income the borrower is allowed to use towards dividends, and the fraction of net proceeds a borrower receives from a financial activity that must be used to reduce any outstanding loan balance (the sweep covenants). The net worth covenant determines the percentage cut-off of net worth that should be compared to the borrower's net income. Finally, financial covenants specify the maximum and minimum levels of various financial ratios for a borrower to be in good standing with creditors.
} 
age and debt capacity of high-SCP firms comes with more restrictive EBITDA and debt servicerelated financial covenants for these firms. The table also shows that high-SCP firms are likely to use a greater variety of assets as collateral for loans than low-SCP firms. Overall, the positive association between supply chain power and loan-covenants-induced cash-flow flexibility and debt capacity in our sample firms suggests that free cash-flow driven agency problems (Jensen, 1986) may be less of a concern for creditors when evaluating the credit risk of a high-SCP firm compared to a low-SCP firm. ${ }^{11}$

Finally, Table 4 provides summary statistics for various firm characteristics, the supply chain power measure and its various components, and the product-market power measures. It shows that there are systematic differences in various firm characteristics between low- and high-SCP firms. In particular, in panel $\mathrm{C}$ of the table, it is evident that supply chain power appears to be positively associated with product-market power. As noted above, these differential firm characteristics suggest that unconditional statistics regarding the price and non-price loan contract terms presented in Tables 2 and 3 may not be sufficient to draw robust conclusions on how supply-chain power affects firms' credit risk unless various firm-specific attributes are also controlled for.

Table 4 is about here

\section{Regression ANALYSiS}

\subsection{Baseline Analysis}

The univariate analysis so far suggests that the firm's supply-chain power is associated with lower loan spreads and less restrictive non-price loan contract terms. In the remaining sections of the paper, we examine whether this relationship remains robust to conditioning on a set of baseline covariates as well as to potential endogeneity of the firm's supply chain power. We begin by estimating the following baseline OLS regression model:

$$
L S P R E A D_{l i j t}=\alpha+\beta . S C P_{i j t}+X_{i j t}^{\prime} . \delta+Z_{l i j t}^{\prime} \cdot \gamma+\mu_{j}+v_{t}+\varepsilon_{l i j t},
$$

\footnotetext{
${ }^{11}$ This is also consistent with Demerjian (2017) who shows that the intensity of covenant use by creditors is positively associated with the extent of informational uncertainty concerning a borrower's future cash flows.
} 
where $L S P R E A D_{\text {lijt }}$ is the logarithm of loan spread over LIBOR for loan $l$ initiated by firm $i$ at time $t$ operating in industry $j .{ }^{12} S C P_{i j t}$ is the firm-level supply-chain power measure. $X_{i j t}$ and $Z_{l i j t}$ control for various firm- and loan-specific attributes, respectively. Finally, $\mu_{j}, v_{t}$, and $\varepsilon_{l i j t}$ are defined as industry fixed effects, year fixed effects, and a noise term, respectively. The main empirical test in this regression setting is whether, all else equal, a high-SCP firm faces systematically different costs to a low-SCP firm when initiating a bank loan. In regression model (1), the $\beta$ captures the effect of supply-chain power on the cost of bank loans conditional on various firm- and loan-specific attributes.

Panel A of Table 5 reports the baseline regression results from equation (1) without controlling for firm- and loan-specific attributes. Across all specifications and components of the aggregate supply-chain power measure, the results show a significantly (at the $1 \%$ level) negative association between a firm's supply chain power and its cost of bank loans. Since the dependent variable in regression model (1) is in logarithmic form, the regression coefficient $\beta$ can be interpreted as semi-elasticity of supply-chain power on the cost of bank loans as follows: $\frac{\text { OSPREAD }}{\text { DSCP }} \times \frac{1}{\text { SPREAD }}$, where SPREAD is the dependent variable (in levels) (in our case, the level of the All-in-Drawn variable). Following this logic, the $\beta$ coefficient in column (1) of Table 5 can be construed as $\triangle S P R E A D=-0.091 \times S P R E A D_{\text {initial }} \times \triangle S C P$. If we evaluate this at the observed loan spread of the average firm in our sample (equivalent to 184.73 basis points in Table 2), a one-standard-deviation (equivalent to 0.9901) increase in the in-sample supply-chain power measure is associated with a 16.64 basis point reduction in loan spread. Compared to the average facility amount of $\$ 94.74$ million for the high-SCP firm sample, the 16.64 basis point reduction in loan spread is equivalent to $\$ 0.1576$ million in annual debt-service savings for these firms. In panel B of the table, we report our baseline regression results controlling for product-market power. ${ }^{13}$ The results show that consistent with prior literature, product-market power is associated with lower cost of debt. More importantly, after controlling for productmarket power, the negative effect of supply chain on the cost of debt remains statistically and economically significant.

One concern with our specification is that supply chain power is simply a proxy for firm profitability. If so, once controlled for in the regression specification, profitability should soak

\footnotetext{
${ }^{12} \mathrm{An}$ industry is identified by the six-digit NAICS industry code within which a firm operates.

${ }^{13}$ We report results only for the HHI measure of product-market power. Results using other measures are available in the Online Appendix.
} 
up all (or most) of the explained variations attributable to supply chain power. While we explicitly control for firm profitability in our subsequent tables, to further alleviate this concern for the unconditional results in this table, we reproduce the results in Table 5 using 11 different specifications to examine whether the reported results in the table remain robust to controlling for firm profitability in a variety of models. These profitability robustness analyses are reported in the online appendix. These results show that supply chain power is not equivalent to profitability and our measure of supply chain power captures information content that is different from the profit potential of the firm. ${ }^{14}$

Table 5 is about here

Table 6 reports the baseline regression results from equation (1) after controlling for firmand loan-specific attributes. For specifications 1-3, the dependent variable is the logarithm of loan spread (Log(All-in-Drawn)) and for specifications 4-6, the dependent variable is the logarithm of the total cost of borrowing ( $\log (\mathrm{TCB})$ ). For both dependent variables, we present results using the primary PCA index of supply chain power for the sake of brevity. For each dependent variable, we first report results controlling for firm and loan characteristics, followed by results controlling for product-market power.

The results show that, across all specifications, supply-chain power has a significantly negative (at the 1\% level) impact on the cost of bank loans. Following the logic mentioned earlier, for the $\beta$ coefficient in regression model (1), the effect of supply chain power on the cost of bank loans in column (1) of Table 6 can be interpreted as $\triangle S P R E A D=-0.113 \times S P R E A D_{\text {initial }} \times$ $\triangle S C P$. As above, if we evaluate this at the observed loan spread of the average firm in our sample, a one-standard-deviation increase in the in-sample supply-chain power measure is associated with a 20.67 basis point reduction in loan spread. Compared to the average facility amount for the high-SCP firm sample, the 20.67 basis point reduction in loan spread is equivalent to $\$ 0.1958$ million in annual debt-service savings for these firms. Assuming that a low-SCP firm has a AAA credit rating with $7.08 \%$ long-term average yield,${ }^{15}$ the total compounded debtservice savings for the firm accumulates to $\$ 1.1278$ million $\left(\frac{0.1958}{0.0708} \times\left((1+0.0708)^{5}-1\right)\right)$ for a loan maturing in 5 years. ${ }^{16}$ Firm size, growth opportunities (measured by Tobin's $q$ ), asset tan-

\footnotetext{
${ }^{14}$ We apply a similar profitability robustness analysis to our subsequent estimates in both our subsequent multivariate regressions and our path analysis, but all our reported results remain robust to these alternative specifications.

${ }^{15}$ See "https://fred.stlouisfed.org/series/AAA" for Moody's Seasoned AAA Corporate Bond Yield.

${ }^{16}$ The median low-SCP firm in our sample has a loan maturity of approximately 5 years in Table 2.
} 
gibility, interest-coverage ratio, facility size and maturity, reputation of the lead lender (big 3 lender dummy), and prior lending relationship are, on average, negatively associated with the cost of bank loans. In contrast, leverage, default risk (EDF), and loan security are positively associated with the cost of bank debt. The signs and significance of these controls are similar to those reported in prior literature (Aivazian et al., 2015; Bharath et al., 2011; Graham et al., 2008). The statistical and economic significance of supply chain power conveyed by the above results remain robust to controlling for loan characteristics as well as product-market power.

Table 6 is about here

\subsection{Baseline Analysis: Alternative Measures of SCP}

As a robustness to our baseline analysis, we introduce additional measures of supply chain power that take into account the relative size of the two parties. ${ }^{17}$ First, we construct a supplychain COGS concentration index to quantify the importance of supply-chain COGS sourcing to customers. We first identify the dollar value (in million \$) of COGS sourced by customer $i$ in year $t$. We then define the concentration index for customer $i$ in period $t$ as follows: $\sum_{s=1}^{N}\left(\frac{\operatorname{COGS}_{s i t}}{\operatorname{COGS})_{i t}}\right)^{2}$, where $C O G S_{s i t}$ is the dollar value of COGS sourced by customer $i$ from supplier $s$ in period $t, C O G S_{i t}$ is the total dollar value of COGS of customer $i$ in period $t$, and $N$ is the number of different suppliers in customer $i$ 's supply chain in period $t$. This construction is similar to a COGS-based Herfindahl-Hirschman index and ranges between 0 and 1. A higher value of the concentration index implies that the bulk of the COGS of a customer is attributed to a few suppliers in the supply chain, making the customer more susceptible to supply-chain related disruptions, thereby lessening the power of the customer over its supply chain. We expect the suppliers concentration index to increase a customer's loan spread. Second, we calculate $\frac{\sum_{s=1}^{N} C O G S_{s i t}}{C O G S_{i t}}$ across all suppliers in customer $i$ 's supply chain in period $t$ to measure the importance of supply-chain COGS sourcing to a customer. A higher value of the measure implies a greater degree of dependence of the customer on its supply chain for COGS sourcing. We expect the supply chain dependence of a customer to favorably affect its cost of bank financing. Third, we divide the number of relationship-based suppliers of customer $i$ in period $t$ by its total number of suppliers in period $t$ to capture the specialized nature of a customer-supplier

\footnotetext{
${ }^{17}$ We thank the referee for this suggestion.
} 
relationship; a supplier is defined as a relationship-based supplier if a customer sources part of its COGS from the supplier more than once over the prior three years. Finally, we use the fraction of COGS from relationship-based suppliers over the total COGS of customer $i$ in period $t$ to capture the importance of specialized inputs in the customer-supplier relationship. A relationship-based supply chain implies greater operational stability of a customer's production process and, hence, we expect lenders to favourably incorporate such supply chain attributes in the credit risk assessment of a firm.

Table 7 is about here

Table 7 reports the OLS estimates of the effects on these additional measures of supply chain power on the cost of bank debt. The results show that when a customer relies on a few concentrated suppliers for its COGS sourcing, thereby lessening its supply chain power, the cost of bank debt increases. In contrast, reliance on distributed supply-chain sourcing, relationship-based suppliers, and relationship-based supply-chain COGS sourcing reduces the cost of bank debt. Our results with alternative measures of supply chain power remain robust after controlling for product market competition. ${ }^{18}$

\subsection{Demand and supply side market power and the cost of debt}

While it is important to consider both supply-side and demand-side interactions for a fuller understanding of the effects of market power on the cost of debt, most existing studies, including Valta (2012) and Xu (2012), examine the effects of product-market competition in isolation. In this section, we examine how the effect of product-market competition on the cost of debt changes if one ignores the supply-side interactions of firms. We begin with the following model from Valta (2012) without considering the supply-side power of firms:

$$
Y=X \cdot \beta+\mu
$$

where $Y$ is the cost of debt, $X$ is the level of product-market competition, including other control variables, and $\mu$ is the standard white noise term. In model (2), the $\beta$ coefficient captures the effect of product-market competition on the cost of external debt financing (we

\footnotetext{
${ }^{18}$ Furthermore, to assuage the concern that for a very large customer, with relatively more suppliers, the SCP may proxy for a nonlinear size effect on the cost of debt, we estimate polynomial (up to degree 10) regressions and find that the beneficial effects of SCP remain robust after controlling for various firm size polynomials. We report these polynomial regressions in the appendix for brevity.
} 
ignore the effects of other controls here for the sake of simplicity). Now if we condition model (2) on a firm's supply-side market power, we can rewrite model (2) as follows:

$$
\begin{array}{ll}
Y_{H}=X_{H} \cdot \beta_{H}+\mu_{H} & \text { if the firm has high supply-side power } \\
Y_{L}=X_{L} \cdot \beta_{L}+\mu_{L} & \text { if the firm has low supply-side power }
\end{array}
$$

We define $S P_{H}$ as an indicator variable set to 1 if a firm has high supply-side market power and 0 otherwise. Similarly, we define $S P_{L}$ as an indicator variable set to 1 if a sample firm has low supply-side market power. We can now combine the two equations in model (3) and rewrite model (2) as follows:

$$
Y=S P_{H}\left(X_{H} \cdot \beta_{H}+\mu_{H}\right)+S P_{L}\left(X_{L} \cdot \beta_{L}+\mu_{L}\right)
$$

We can also rewrite the above model in the following manner:

$$
Y=X \cdot \beta_{H}+S P_{L} \cdot X_{L} \cdot\left(\beta_{L}-\beta_{H}\right)+\mu^{*}
$$

where $\mu^{*}=S P_{H} \cdot \mu_{H}+S P_{L} \cdot \mu_{L}$. In the specification (5) above $\beta_{L}-\beta_{H}$ captures the difference in the effect of product-market power on the cost of debt financing conditional on low versus high supply-side market power. We estimate specification (5) using our data and test the difference parameter $\beta_{L}-\beta_{H}$ using a Wald test statistic, i.e., an $\mathrm{F}$ test.

\section{Table 8 is about here}

Table 8 reports our estimation from model (5). Column (1) of Table 8 shows the effect of product-market competition on the cost of bank loans depending on whether a firm has high or low supply-chain power in its supply-side interactions. ${ }^{19}$ The results show that for high-SCP firms, product-market competition significantly reduces cost of bank loans at the $1 \%$ level of significance, captured by the $\beta_{H}$ coefficient. In addition, the external debt financing benefit of product-market competition is much more pronounced for firms with high supply chain power compared to the average firm in our sample, i.e., the value of $\left|\beta_{H}\right|$ is more than twice as large as the coefficient on $|H H I|$ (0.885) in column (3), Table 6. In other words, empirical studies, such as Valta (2012), which examine the external debt financing effects of product-market competition are likely to underestimate the benefits for firms that also enjoy

\footnotetext{
${ }^{19}$ We use the sample median of a variable as the cutoff point to differentiate between high and low levels of that variable.
} 
high market power in their upstream (supply-side) operations. Further, the results in column (1) also show that $\beta_{L}-\beta_{H}>0$, suggesting that the effects of product-market power on the cost of bank loans differ systematically and significantly (at the 1\% level) between low- and high-SCP firms. This suggests that prior studies are also likely to overestimate the external debt financing benefit of product-market competition, captured by the coefficient -0.885 in column (3) of Table 6, for firms with low supply chain market power. In sum, the results in column (1) of Table 8 imply that unconditional (with respect to supply-side) estimates of the effects of product-market competition on the cost of debt are likely to be biased in either direction, depending on the degree as well as the extent of a firm's market power in its supply chain. Column (2) of the table presents results for the customer concentration measure of Patatoukas (2012), and indicate that a greater customer concentration (less product-market competition) is associated with relatively lower loan costs for low-SCP than for high-SCP firms.

We note that a similar criticism also applies to studies that examine the effect of supplyside power in isolation. However, the results in column (3) of Table 8 show that the likely bias in the estimate of the effect of $S C P$ on the cost of bank loans, when ignoring productmarket competition, is much smaller than the equivalent bias in product-market competition. For instance, the unconditional (with respect to product-market competition) effect of $S C P$ in column (2) of Table 6, i.e., $\beta=-0.045$, is virtually the same as the conditional effect (conditional on high product-market competition) in column (3) of Table 8, i.e., $\beta_{H}=-0.048$. Furthermore, $\beta_{L}-\beta_{H}>0$ in column (3) of the table, suggesting that when a firm has low upstream market power, the external debt financing benefit of product-market competition becomes much more pronounced. We also perform similar exercises for the supply-chain power and customer concentration and the results in columns (2) and (4) suggest that the debt benefit of customer concentration is more pronounced for low-SCP firms. However, when a firm has high customer-base concentration, the debt benefit of supply chain power also increases.

\subsection{Inferring Causality I: AN Instrumental Variables (IV) ANalysis}

A potential identification issue with the OLS estimation is the endogeneity of supply-chain power. It is plausible, for example, that firms that are more likely to benefit from supply-chain power are also firms that rely heavily on specific types of production processes that enhance their power. In other words, there could be additional unmeasured effects that affect both the 
firm's degree of power to control its supply chain and its cost of bank loans, thereby leading to an omitted variable bias. A common way to deal with the endogeneity problem is by using an Instrumental Variables (IV) approach. Under this approach, we need to find an instrument that is correlated with supply-chain power, but is unrelated to the cost of bank loans and the error in the regression.

We instrument the firm's supply-chain power with a measure that captures the geographical dispersion (based on the longitude and latitude of a supplier's ZIP code) among its suppliers. We argue that geographical dispersion among suppliers within a firm's supply chain increases co-ordination problems among its suppliers and, as a result, the firm is less likely to experience a supplier "hold-up" problem during the course of production, significantly reducing its business risk. This, in turn, can engender a greater incentive for the firm to rely on a geographically dispersed supply chain. Although suppliers' locations do not directly affect the information set of banks, it is possible that suppliers' locations may change over time. If the decision of a supplier to relocate is not orthogonal to the bank's information set, the geographical dispersion among suppliers may not be excludable from the bank-loan spread regression analysis. To address this concern, we manually check the 10-K filings of our sample suppliers and identify those that changed their business addresses during our sample period. We then exclude all those supply chains from our IV analysis if they contain any supplier that relocated. ${ }^{20}$

To construct the instrument for firm $i$ in period $t$, we first calculate the mean absolute deviation of distances among its suppliers as follows:

$$
M A D D_{i t}=\frac{\sum_{k, l \in(1 . . N)}\left|D I S T_{i t}^{k, l}-\overline{D I S T_{i t}^{k, l}}\right|}{N_{i t}} \forall k \neq l,
$$

where $M A D D_{i t}$ is the mean absolute deviation of the geographical distances among all suppliers within firm $i$ 's supply chain in period $t .{ }^{21} D I S T_{i t}^{k, l}$ is the geographical distance between suppliers $k$ and $l$ in firm $i$ 's supply chain in period $t, \overline{D I S T_{i t}^{k, l}}$ is the average geographical distance among all suppliers within firm $i$ 's supply chain in period $t$, and $N_{i t}$ is the total number of suppliers in firm $i$ 's supply chain in period $t .{ }^{22}$ For instance, if a firm has 5 different suppliers in

\footnotetext{
${ }^{20}$ We thank the referee for this suggestion.

${ }^{21}$ We use the mean absolute deviation instead of standard deviation because the standard deviation is undefined for a firm with a single supplier in a given year.

${ }^{22}$ We do not include the distance between firm $i$ and any of its suppliers in our $M A D D_{i t}$ measure. Instead, the measure is calculated based solely on distances among suppliers of firm $i$.
} 
a given year, the $M A D D_{i t}$ is calculated based on 10 different combinations of geographical distances, i.e., $\left(\begin{array}{l}5 \\ 2\end{array}\right)={ }^{5} C_{2}=\frac{5 \times 4}{2 \times 1}=10$. We then use the logarithmic transformation of the measure, i.e., $\log \left(1+M A D D_{i t}\right)$, as our instrument for supply chain power. ${ }^{23}$

Table 9 is about here

Columns (1) and (2) of Table 9 report our IV regressions only for those customers that did not have any of the relocating suppliers in their supply chains. As suggested by Larcker and Rusticus (2010), we report the first-stage results along with necessary tests for all IV estimations. In the first stage, the instrument is significantly positively correlated, as desired, with our supply chain power measure with high t-statistics and F-statistics. In the second stage, supply chain power is significantly related to loan spread and the negative relationship is significant at the $1 \%$ level. The signs and statistical significance of all the firm-specific and loan-specific characteristics are similar to the OLS regression except for the magnitudes of those effects. To test for the existence of endogeneity, we use the Hausman specification test (Hausman, 1978). The Hausman test is based on the difference between the OLS estimator (which is consistent and efficient under the null hypothesis of no endogeneity, but inconsistent under the alternative) and the IV estimator (which is consistent under both, but inefficient under the null). We can reject the null hypothesis of no endogeneity at the $1 \%$ level of significance, suggesting that the IV specification is more efficient than the simple OLS specification. Simply put, supply chain power lowers the cost of bank loans and this effect is robust to possible endogeneity concerns.

One thing to note is that the coefficient on our supply chain power measure becomes significantly more negative in our instrumental variable estimation. The stronger negative coefficient, after controlling for endogeneity, can be explained by the correlation of a firm's supply chain power with its performance. As can be seen from Table 4, firms that exert a great deal of power over their supply chains tend to be less profitable. Thus, not controlling for omitted (negative) performance attributes might lead the coefficient of supply chain power to partially capture the positive effect of poor profitability on the cost of debt and bias the OLS estimate toward zero. After controlling for the endogeneity of supply chain power due to omitted variables, the negative effect of supply chain power on loan costs is likely to be more pronounced. ${ }^{24}$

\footnotetext{
${ }^{23}$ Since the distance measure ranges over several orders of magnitude in some cases, the logarithm minimizes the impact of outliers.

${ }^{24}$ For robustness, we also test two variations of our instrument. First, we use the difference between the geographical distances of the $75^{t h}$ and the $25^{\text {th }}$ percentile suppliers in the distribution of distances among all suppliers of a firm in a given year, i.e., the inter-quartile distance.
} 
However, one could also argue that the loan spread decision and the choice of a firm's supply chain (and by implication, the dispersion among a firm's suppliers) may be co-determined, potentially polluting our instrument. To alleviate any such concern, we introduce an alternative instrument. To construct the new instrument for each customer $i$ in period $t$, we collect all nonzero amounts of minority interest in the suppliers' balance sheets. A nonzero minority interest indicates that, at some point in time, the supplier firm may be acquired by another firm resulting in disruptions in the supply chain of customer $i$. A supply chain prone to disruption is likely to lessen the supply chain power of a customer. Since minority interest is determined by past acquisition activities related to suppliers, it is unlikely to be contemporaneously correlated with the loan spread of the customer. We use the average minority interest across all suppliers of customer $i$ in period $t$ as our instrument for customer $i$ 's supply chain power. Columns (3) and (4) of Table 9 reports our IV analysis using the alternative instrument. The results show that the average supply chain minority interest is indeed negatively and significantly associated with supply chain power in the first stage and instruments satisfies the exclusion restriction test. More importantly, our results establishes a casual link between supply chain power and the cost of bank debt by showing that the instrumented supply chain power significantly (at the $1 \%$ level) reduces the loan spread for our sample of firms. ${ }^{25}$

\subsubsection{Simultaneity Of Price And Non-Price Contract Terms}

Our results so far suggest that supply-chain power reduces the cost of bank loans. However, besides the costs of the loan, non-price debt contract terms can also impose indirect costs on borrowing firms. For example, firms may incur higher transaction costs if they are forced to refinance more frequently, managers may spend more time dealing with more frequent debt issues, and firms may forgo profitable investment opportunities as a result of additional debt covenant restrictions. Barclay and Smith (1995) show that short-term bank loans help enhance monitoring. For example, by reducing the debt term, a bank can maintain a stronger bargaining position. Banks can also periodically evaluate the firm's ability to pay off debt through a shortterm debt-renewal process. Jensen and Meckling (1976), Smith and Warner (1979), Aivazian and Callen (1980) and others argue that firms with greater agency problems benefit from more

Second, we compute the standard deviation of distances between the firm and its suppliers. Since the results are qualitatively similar in both cases, we do not report them for brevity.

${ }^{25}$ We also examine the robustness of our single equation IV results by simultaneously incorporating endogeneity of product-market competition and the results are reported in the online appendix. 
collateral and restrictive covenants on their debt to reduce moral hazard problems. Although it is difficult to quantify such costs, testing for the effect of supply-chain power on the cost of bank loans could be confounded by the interdependencies between price and non-price terms of credit. From an estimation point of view, complications may also arise due to the joint determination of price and some non-price debt-contract terms. To understand how supplychain power affects the overall cost of bank loans via non-price terms, following Bharath et al. (2011), we focus on the maturity and collateral terms of the contract and estimate the following simultaneous equation model:

$$
\begin{aligned}
& L S P R E A D_{\text {lijt }}=\alpha_{1}+\beta_{1} \cdot S C P_{i j t}+\pi_{1} \cdot C O L L A T E R A L_{i j t}+\psi_{1} \cdot \text { MATURITY }_{i j t} \\
& +X_{i j t}^{\prime} \cdot \delta_{1}+Z_{l i j t}^{\prime} \cdot \gamma_{1}+\mu_{j}+v_{t}+\varepsilon_{l i j t} \\
& \text { MATURITY } Y_{\text {lijt }}=\alpha_{2}+\beta_{2} \cdot S C P_{i j t}+\pi_{2} \cdot \text { COLLATERAL } L_{i j t} \\
& +X_{i j t}^{\prime} \cdot \delta_{2}+Z_{l i j t}^{\prime} \cdot \gamma_{2}+\mu_{j}+v_{t}+\varepsilon_{l i j t} \\
& \operatorname{COLLATERAL~}_{\text {lijt }}=\alpha_{3}+\beta_{3} \cdot S C P_{i j t}+\psi_{3} \cdot \operatorname{MATURITY_{ijt}} \\
& +X_{i j t}^{\prime} \cdot \delta_{3}+Z_{l i j t}^{\prime} \cdot \gamma_{3}+\mu_{j}+v_{t}+\varepsilon_{l i j t} \text {, }
\end{aligned}
$$

where MATURIT $Y_{i j t}$ is the maturity (in months) of a loan; and COLLATERAL $L_{i j t}$ is a dummy variable indicating whether the loan is collateralized. We assume, following Bharath et al. (2011), that maturity and collateral affect each other (bidirectional relationship) while spread is only affected by maturity and collateral (unidirectional relationship). The loan spread variable is not included in any of our regressions of non-price terms because the typical process of syndication suggests that the loan price is determined after all other non-price terms have been settled. ${ }^{26}$

A complication arises in estimating the above system because spread and maturity are continuous variables, while security is a dichotomous variable. To address this issue, we follow Wooldridge (2002), who shows that estimating a Logit model in the first stage and using the fitted value as an instrument for the dichotomous variable in the second stage results in a consistent estimate. For the two endogeneous variables in the spread equation, maturity and

\footnotetext{
${ }^{26}$ S\&P's (2011) "A Guide to the Loan Market" describes the process of loan issuance in several discrete steps. The process starts with the borrower appointing the lead bank, which conducts due diligence and negotiates the non-price loan features such as amount, collateral, maturity, and covenants with the borrower and leaves the final price to be determined. The lead bank then informally polls potential syndicate members to gauge the level of interest in the loan and uses the information to set the interest rate on the loan. Finally, it is launched for syndication.
} 
collateral, we use two different instruments. Hart and Moore (1994) argue that firms attempt to match their debt maturity to the maturity of their real assets. Barclay and Smith (1995) use asset maturity and a regulated industry dummy as instruments for debt maturity. We follow Barclay, Marx, and Smith (2003) and estimate a firm's asset maturity as: $\left(\frac{C A}{C A+P P E} \times \frac{C A}{C O G S}\right)+\left(\frac{P P E}{C A+P P E} \times \frac{P P E}{D \& A}\right)$, where $C A$ is current assets; $P P E$ is net PP\&E, COGS is the cost of goods sold, and $D \& A$ is depreciation and amortization. We use this proxy for the firm's asset maturity as an instrument for its loan maturity. To instrument for collateral, we use a measure of loan concentration following Berger and Udell (1990) as: $\frac{\text { Loan Amount }}{\text { Existing Debt + Loan Amount }}$.

$\overline{\text { Table } 10 \text { is about here }}$

Table 10 reports the results from the simultaneous regression model (6). Note that there is no simultaneity issue for the spread equation since the loan spread does not enter the maturity and collateral equations as an explanatory variable. Thus, a simple OLS estimation suffices for the loan spread equation. Column (1) of Table 10 reports the OLS estimates of the spread equation, which is the same as the results in column (2) of Table 6. Columns (2) and (3) of Table 10 report the results where maturity and collateral are replaced with the fitted values of the first-stage regressions from the instrumental variables estimations of maturity and collateral equations. Both columns show that, similar to the OLS results, supply-chain power reduces the cost of bank loans, even after controlling for product-market competition (in column 3). To get a sense of the economic significance of this result, when supply-chain power increases from low ( $5^{\text {th }}$ percentile) to high $\left(95^{\text {th }}\right)$ in column 2 , the cost of bank loans declines by 12.03 basis points for the average sample firm with an average loan spread of 184.73 basis points. Columns (4) to (6) report the results for the maturity equation. In particular, the instrumental variables regression results in columns (5) and (6) show that supply-chain power has a positive effect on loan maturity, conditional on other firm- and loan-specific attributes. As noted earlier, a shorter loan maturity may imply more frequent refinancing and thus higher transaction costs for firms. Finally, columns (7) to (9) report the results for the collateral equation. Across all the models, we cannot reject the hypothesis that the loan cost is disproportionately higher for firms with relatively lower supply-chain power than firms with relatively higher supply-chain power, even after addressing the interdependencies between price and non-price contract terms of a debt contract. 


\subsection{INFERRING CAUSALITY II: A QUASI-EXPERIMENTAL APPROACH}

Atanasov and Black (2016) argue that shock-based research designs form a stronger basis for credible causal inference. Hence, to complement our IV analysis, in this section, we use two exogenous (negative) shocks to firms' demand for and supply of financing as quasi-experiments to isolate the direction of causality from supply-chain power to the cost of bank loans. Conventional wisdom suggests that external financing constraints of firms normally become tighter during periods of economic disruption. However, the supply chain power of firms can alleviate such (exogenously imposed) credit constraints by providing supply-chain-powerful firms the option of accessing supply-chain-related financing (such as trade credit) and bypassing the external capital market during periods of heightened capital-market frictions (PWC, 2014; Yang and Birge, 2017). Since an exogenous (unanticipated) shock is unrelated to unobservables affecting both the supply chain power and the loan spread by design, such transitory shocks are likely to generate purely exogenous variations in cross-sectional loan spread and supply chain power. For instance, the conditional effect of supply chain power on loan spread $(\beta)$ in equation (1) can be expressed as: $E(Y \mid S C P, X)_{Z=0}=\beta$, where $Y$ is the logarithm of loan spread, $S C P$ denotes supply chain power, $X$ is the set of baseline covariates, and $Z=0$ implies a noshock regime. When an exogenous shock alters the correlation structure among variables, the conditional effect will change to: $E(Y \mid S C P, X)_{Z=1}=\beta^{\prime}$, where $Z=1$ implies a shock regime. As long as the shock is unrelated to unobservables affecting both the loan spread and the supply chain power, the change in the conditional effect of supply chain power on the loan spread between the shock and no-shock regimes, i.e., $\Delta=E(Y \mid S C P, X)_{Z=1}-E(Y \mid S C P, X)_{Z=1}=\beta^{\prime}-\beta$, must be driven primarily by the cross-sectional variations in supply-chain power. To operationalize this idea, we augment our baseline OLS regression model as follows:

$$
\begin{aligned}
L S P R E A D_{l i j t}=\alpha & +\beta . S C P_{i j t}+\theta . S H O C K_{i j t}+\lambda .\left(S C P_{i j t} \times S H O C K_{i j t}\right) \\
& +X_{i j t}^{\prime} \cdot \delta+Z_{l i j t}^{\prime} \cdot \gamma+\mu_{j}+v_{t}+\varepsilon_{l i j t},
\end{aligned}
$$

where $S H O C K_{i j t}$ is the dichotomous exogenous shock to firms' credit risk and the interaction term $\lambda$ captures the differential effect of supply chain power on the cost of bank loans during periods of heightened capital-market frictions. To empirically estimate the regression model (7), we use two different economic shock measures. 
The first measure, from Baker, Bloom, and Davis (2016), captures the aggregate economic and policy-related uncertainty that is beyond an individual firm's control but affects all firms. The measure is an equally weighted index of the following series: monthly news articles containing terms such as "uncertain" or "uncertainty", "economic" or "economy", and policyrelevant terms such "policy", "tax", "spending", "regulation”, "federal reserve”, "budget", and "deficit" (scaled by the smoothed number of articles containing 'today'); the number of tax laws expiring in coming years; and a composite of interquartile ranges for quarterly forecasts of federal government expenditures and 1-year Consumer Price Index (CPI) from the Philadelphia Fed Survey of Forecasters. A higher value of the index implies a greater degree of economic and policy-related uncertainty. ${ }^{27}$ Based on the uncertainty index, we construct our dichotomous variable UINDEX that returns 1 if the uncertainty index of Baker et al. (2016) is above the sample median, and 0 otherwise.

The second measure is an exogenous liquidity shock specific to loan supply to firms in our sample. It is a dichotomous variable indicating whether the lead bank in a given loan contract initiated between 2001 and 2003 is a subsidiary of a Japanese parent bank. KPMG (2011) notes that real estate loan balances in Japanese banks' portfolios declined "from 1999 through 2003 when Japanese companies implemented balance sheet restructuring after the conclusion of the bubble era (which came to an abrupt end in the early 1990s)". ${ }^{28}$ Peek and Rosengren (2000) and Benmelech, Bergman, and Seru (2015) show that the collapse of the real estate market in Japan adversely affected the lending of Japanese banks and their subsidiaries in the real-estate and industrial sectors in the US.

Table 11 is about here

Table 11 shows results from the augmented OLS regression model. For each shock measure, the table first shows the effects of supply chain power on the cost of bank loans during highand low-uncertainty periods and then shows the differential effects by combining both highand low-uncertainty samples. The table shows that the beneficial effect of supply chain power on the cost of bank loans is more pronounced during high-uncertainty periods than in low-

\footnotetext{
${ }^{27}$ For robustness, we use two other uncertainty measures. The first is from Alexopolous and Cohen (2009). They use the log of the total number of articles appearing each month in the New York Times that contain references to uncertainty and the economy as their index of uncertainty. The second is the implied volatility of S\&P 500 index options from the Chicago Board Options Exchange Market Volatility Index $(V I X)$. Our results remain quantitatively and qualitatively similar using these alternative measures of uncertainty.

${ }^{28} \mathrm{We}$ also use the loan share of the Japanese lead bank during this period as an alternative measure of loan-level supply shock.
} 
uncertainty periods. Our results are even stronger in terms of economic significance when we focus on the loan-level liquidity supply shock. These results suggest that the supply chain power becomes particularly valuable for firms, from a credit-risk perspective, during periods of elevated capital-market frictions. Finally, columns (4)-(6) of Table 11 show the the beneficial effects of supply chain power during uncertain economic times remain intact when controlling for product-market power as well.

\subsection{INFERRING CAUSALITY III: HOLD-UP RISK AND LOAN SPREAD}

To address the concern that our cross-sectional regression setting (without firm-fixed effects) may pick up the opposite channel, i.e., lower loan cost leads to higher supply chain power, we identify customer-supplier relationships that are more susceptible to hold-up risk. When a firm's supply chain is more susceptible to hold-up risk, it is reasonable to argue that the firm is more likely to face higher loan cost irrespective of banking relationships. It is well known that the hold-up problem in a supply chain emerges when one firm in the relationship is able to expropriate the returns from an investment made by another firm (Rogerson, 1992; Klein, 1998; Williamson, 1985) and the condition of asset specificity is central to this problem (Coase, 2006).

We identify firms in our sample that are more susceptible to hold-up risk based on the extent of their asset specificity. Following Kim and Kung (2017) and Kim (2018), we construct a measure of firm-level asset specificity, where a higher degree of asset specificity implies lower redeployability of assets outside the supply-chain relationship. ${ }^{29}$ We define a supply chain as more susceptible to hold-up risk if both the supplier and the customer are in the top quartile of their respective asset specificity measures. ${ }^{30}$ Similarly, we define a supply chain as not susceptible to hold-up risk if both the supplier and the customer are in the bottom quartile of their respective asset specificity measures.

$$
\text { Table } 12 \text { is about here }
$$

Table 12 reports our results on the effect of hold-up risk on the cost of bank loan, conditional of firms' supply chain power. Column (1) of the table shows that if a customer-supplier

\footnotetext{
${ }^{29}$ Available at: http://blogs.cornell.edu/hyunseobkim/asset-redeployability/

${ }^{30}$ We report the list of sample customer firms that are more susceptible to supply-chain hold-up risk in the Online Appendix.
} 
relationship is more susceptible to hold-up risk, the customer tends to have elevated credit risk manifested by a higher cost of bank loans. In columns (2) and (3), we partition the sample firms into high supply chain power (high-SCP) and low supply chain power (low-SCP) and reestimate our OLS model with the primary focus on the effect of hold-up risk on the cost of debt. The results show that the detrimental effect of hold-up risk disappears for high-SCP firms but remains persistent for low-SCP firms. Finally, in column (4), we interact supply chain power with hold-up risk and find that higher supply chain power can attenuate the adverse effect of hold-up risk on a firm's cost of bank debt. We perform a similar experiment by partitioning our sample firms into 'hold-up' and 'no-hold-up' and estimate our OLS model with the primary focus on the effect of supply chain power on the cost of debt. Results in columns (5)-(7) show that supply chain power reduces the cost of bank debt but the presence of hold-up risk can significantly diminish the beneficial effects of supply chain power on the cost of bank debt. ${ }^{31}$

\subsection{Supply Chain Power, loAn SpRead, AND the Specificity of Supply Chain}

The above analysis establishes the causal effect of supply chain power on the cost of bank loans. However, it is well known that not all supply chains are the same. For instance, data compiled by Bloomberg's supply chain database (SPLC) show that general retailers such as Walmart rely on hundreds of suppliers (732 for Walmart) while specialized retailers such as Toys"R"Us rely on relatively fewer suppliers (26 for Toys"R"Us). Furthermore, Walmart's cost of goods sold (COGS) share from its top 10 COGS suppliers (in terms of relationship value) is relatively more evenly distributed among those suppliers while for Toys"R"Us, two suppliers (out of the top 10) account for most of its COGS share. ${ }^{32}$

These observations point to two key issues: first, a firm's supply chain can be thickly populated (e.g., Walmart) giving the firm significant leverage to switch between suppliers at ease. We label this type of supply chain as arm's length. In contrast, a thinly populated supply chain gives a firm little power to switch between suppliers, thereby effectively locking the firm into a more relationship-specific chain. Second, the credit risk implications of supply chain power may vary significantly depending on whether the firm relies on an arm's-length or a relationship-specific supply chain. This is because a relationship-specific supply chain reduces

\footnotetext{
${ }^{31}$ The number of observation in these regression analyses declines significantly due to the availability of the firm-level asset specificity data.

${ }^{32}$ See the Online Appendix for a list of top 10 suppliers of Wal-mart.
} 
supply-chain related uncertainty but also comes with reduced flexibility for the downstream firm since the cost of production outside the relationship increases significantly (Klein, Crawford, and Alchian, 1978; Williamson, 1979, 1985). Furthermore, a relationship-specific supply chain also requires relationship-specific investment and, as discussed earlier, the market liquidity of relationship-specific assets declines significantly during financial distress as such assets have little value outside the relationship (Shleifer and Vishny, 1992). Therefore, a relationshipspecific supply chain can significantly increase the degree of counter-party risk within the supply chain (Boyarchenko and Costello, 2015). In contrast, an arm's-length supply chain ensures that both parties in the deal are acting in their own self-interest and are not subject to duress from the other party, i.e., no party has any significant bargaining power, thereby increasing supply-chain related uncertainty but also increasing operational flexibility. Furthermore, assets related to an arm's-length supply chain may not experience significant value loss in distress. Therefore, how the effect of supply chain power on loan spread varies depending on the specificity of the supply chain, i.e., arm's-length as opposed to relationship-specific, is an empirical question.

To empirically measure supply chain specificity, we resort to an industry-level classification metric, as most databases (e.g., Bloomberg's SPLC) only provide relatively short histories of firm-level supply-chain characteristics. We modify a measure developed by Nunn (2007) who argues that if an input is sold on an exchange or reference-priced in trade publications, then the market for the input is thick, with many alternative buyers and sellers. A thick market for an intermediate input also implies that the transaction involving the input is arm's-length as opposed to relationship-specific. Following Nunn (2007), we measure the industry-level supply-chain specificity (ISCS) for each 6-digit manufacturing industry as follows: $I S C S_{i}=$ $1-\sum_{j} \theta_{i j}\left(R_{j}^{n o n-e x c h}\right)$, where $\theta_{i j}=\frac{u_{i j}}{u_{i}}, u_{i j}$ is the value of input $j$ used in industry $i$ and $u_{i}$ is the total value of all inputs used in industry $i, R_{j}^{\text {non-exch }}$ is the proportion of input $j$ that is not either sold on an organized exchange or reference priced. A higher value of $I S C S_{i}$ implies an arms'-length supply chain since the market for intermediate input for the final product $i$ is thick. $^{33}$

\footnotetext{
${ }^{33}$ We report the distribution of ISCS $i$ across 6-digit NAICS industries for the US manufacturing firms in the Online Appendix. For instance, for a "Computer Storage" manufacturer (NAICS 334112), only 5.823\% of intermediate inputs are either sold on organized exchanges or are reference-priced, i.e., the production process is highly relationship-specific. In contrast, for an "Aluminum Sheet, Plate, and Foil" manufacturer (NAICS 331315), 94.695\% of intermediate inputs are sold on organized exchanges, i.e., the production process is primarily arm's-length. Therefore, we hypothesize that an aluminum foil manufacturer will have more real flexibility in adjusting inventory and production than a computer-storage device manufacturer.
} 
Table 13 is about here

Table 13 reports the effects of supply chain power on loan spread depending on the relationship specificity of the supply chain. To estimate the conditional effect (conditional on supply chain specificity) of supply chain power using OLS, we create a firm-level dummy variable. If a firm is embedded in an industry with supply chain specificity measure (ISCS) above the $75^{\text {th }}$ percentile of its distribution, we classify the firm as more dependent on an arm's-length supply chain and denote the dummy variable as 1 . In contrast, if a firm is embedded in an industry with supply chain specificity measure below the $25^{\text {th }}$ percentile of its distribution, we classify the firm as more reliant on a relationship-specific supply chain and denote the dummy variable as 0 . The interaction of this dummy variable with our main measure of supply chain power captures the effect of excessive reliance on arm's-length supply chain as opposed to relationship-specific supply chain for a firm.

The table shows that, irrespective of the specificity of the supply chain, supply chain power reduces loan cost. Moreover, creditors value arm's-length supply chains more favorably than relationship-specific supply chains, suggesting that from creditors' perspectives, the benefits associated with the operational flexibility of an arm's-length supply chain outweighs the costs of such production-related arrangements. Interestingly, however, excessive reliance on an arm'slength supply chain by a high supply-chain-power firm appears to have a detrimental impact on its loan cost. Overall, we conclude that a high degree of supply chain power reduces firm-level external debt financing constraints on average, and the effect is augmented for high-supplychain-power firms that invest more in relationship-specific assets within the supply chain.

\subsection{Is Supply Chain PoWer Related To BankRuptcy Risk?}

Our analysis so far has been geared towards establishing a causal and robust relationship between a firm's supply-chain structure and its cost of external bank-loan financing. We show, through causal inferences and robust regression analysis, that supply-chain power indeed reduces the cost of bank loans and, by implication, also significantly affects firm-level credit risk. A logical extension of this argument is that the credit risk implications of supply-chain power should also be reflected in the expected bankruptcy risk of firms. Therefore, in this section, we analyze whether supply-chain power significantly affects firm bankruptcy risk. 
Specifically, we construct 4 different measures of firm-level bankruptcy risk used extensively in the accounting and finance literature. Following Altman (1968), we construct the Z-Score; a higher value of the Z-Score implies a lower likelihood of default. ${ }^{34}$ Following Ohlson (1980), we calculate the O-Score measure; a higher value of the O-Score measure implies a higher likelihood of bankruptcy. ${ }^{35}$ We follow Bharath and Shumway (2008) and construct a distanceto-default measure as follows: $D T D=\frac{\ln (V / F)+\left(\mu-0.5 \sigma_{V}^{2}\right) T}{\sigma_{V} \sqrt{T}}$, where $V$ is the total value of the firm, $F$ is the face value of the firm's debt, $\mu$ is the expected continuously compounded return on $V$, $\sigma_{V}$ is the volatility of firm value, and $T$ is the default risk forecasting horizon. A higher value of DTD implies that the firm is further away from its default boundary and hence there is a lower likelihood of default. Finally, we create a dummy variable indicating whether a firm has an investment grade S\&P long-term credit rating, which implies a lower likelihood of default.

Table 14 is about here

Panel A of Table 14 reports the correlation between loan spread and our four different bankruptcy risk measures. It is obvious from the table that all measures of bankruptcy risk are significantly correlated with loan spread and, as expected, the correlation analysis shows that higher (lower) risk of bankruptcy is positively (negatively) associated with loan spread. In panel B of the table, we report our OLS (specifications 1-3 and 5-7) and LOGIT (specifications 4 and 8) regression results where the dependent variable is one of the bankruptcy risk measures and the primary independent variable is a dummy variable indicating whether a firm has high power in its supply chain. Across all specifications and bankruptcy-risk measures, the results show that a higher degree of supply-chain power is associated with a lower likelihood of default. These findings are consistent with our causal analysis earlier on the effects of supply chain power on the cost of bank loans. The analysis presented here suggests that supply chain power reduces bankruptcy risk, thereby lowering the credit risk of firms. Lower bankruptcy risk, in turn, alleviates external financing constraints, leading to a lower bank-loan spread.

\footnotetext{
${ }^{34}$ ZSCORE $=\left(1.2 \times X_{1}\right)+\left(1.4 \times X_{2}\right)+\left(3.3 \times X_{3}\right)+\left(0.6 \times X_{4}\right)+\left(1.0 \times X_{5}\right)$, where $X_{1}$ is defined as working capital/total assets, $X_{2}$ is defined as retained earnings/total assets, $X_{3}$ is defined as earnings before interest and tax/total assets, $X_{4}$ is defined as market value of equity/total liabilities, and $X_{5}$ is defined as sales/total assets.

${ }^{35}$ OSCORE $=-1.32-(0.407 \times$ Size $)+(6.03 \times$ TLTA $)-(1.43 \times$ WCTA $)+(0.0757 \times C L C A)-(1.72 \times$ DUM 1$)-(2.37 \times N I T A)-(1.83 \times$ $C F T L)+\left(0.285 \times D U M_{2}\right)-(0.521 \times C H I N)$, where Size is defined as $\log$ (total assets /GNP price level index), TLTA is defined as total liabilities/total assets, WCTA is defined as working capital (WC)/total assets (TA). CLCA is defined as current liabilities (CL)/current assets (CA), NITA is defined as net income (NI)/total assets (TA), CFTL is defined as cash flows from operation (CF)/total liabilities (TL), CHIN is defined as $N I_{t}-N I_{t-1}$ divided by the sum of the absolute values of $N I_{t}$ and $N I_{t-1}$. DUM $M_{1}$ is a dummy variable that is set equal to 1 if total liabilities are greater than total assets, and 0 otherwise, while $D U M_{2}$ is another dummy variable that is set equal to 1 if net income was negative for the last two consecutive years, and 0 otherwise.
} 


\section{How Does Supply Chain Power Affect Credit Risk?}

In the final stage of our analysis, we examine a potential channel through which supply chain power affects the cost of external financing. Inventory-related risk is an important factor for firm operations, and firms frequently restructure their supply chains to reduce the risk of a disruption in inventory. For example, Barker and Campbell (2018) describe how, in the United Kingdom (UK), firms such as Honda have explicitly mentioned the cost of inventory management as a reason to restructure their supply chains away from the UK following Brexit. Prior literature has shown that in addition to product-market competitiveness, inventory management efficiency also affects the cost of external financing. Since we explicitly control for the effect of product-market competition in previous sections, in this section we focus on inventory management efficiency and use mediation analysis to show that supply chain power reduces inventory-related risk for firms which, in turn, leads to lower credit risk and lower cost of debt.

It has been well documented in the finance and accounting literature that excess inventory hurts the financial and operating performance of firms. Sloan (1996) documents that firms with high levels of accruals, of which the change in inventories is one component, significantly under-perform relative to those with low accruals. Thomas and Zhang (2002) show that the component of accruals that seems to drive such under-performance is in fact the change in inventories. Belo and Lin (2012) find that, after controlling for firm size, firms with higher inventory growth earn lower returns. Jones and Tuzel (2013) examine the relation between inventory investment and the cost of capital in the time series and the cross section; they show that risk premiums of firms are strongly negatively related to future inventory growth at the aggregate, industry, and firm levels. Constructing a production-based asset pricing model with two types of capital, fixed capital and inventories, they argue that convex adjustment costs and a counter-cyclical price of risk lead to negative time series and cross-sectional relations between expected returns and inventory growth. Ak and Patatoukas (2016) show that manufacturers with more concentrated customer bases hold smaller inventories for shorter time horizons and are less likely to end up with excess inventories and subsequently, are associated with a valuation premium.

Chopra and Sodhi (2004) argue that inventory risk hinges on three factors: first, the value 
of the product (holding excess inventory for products with high value can be very costly), second, its rate of obsolescence (holding excess inventory for products with short life cycles can get expensive), and finally, uncertainty of demand and supply (inventory risk increases remarkably fast as product variety grows). Supply chain management is primarily about matching supply and demand effectively. Too much supply leads to inefficient capital investment, expensive markdowns, and needless handling costs, while too much demand generates opportunity costs of lost margins (Cachon, 2004). A crucial component of the matching process between supply and demand is a firm's inventory control system and reliance on a supply chain enables firms to mitigate inventory-related risk. Specifically, companies can minimize inventory risk by working with a highly responsive supplier, especially for high-value, short life-cycle products (Lai, Debo, and Sycara, 2009). The literature on supply chain management and inventory control converge on the idea that reliance on an effective supply chain is one of the most effective ways of mitigating production risk related to inventory distortions (Chopra and Sodhi, 2004).

Combining insights from these different strands of literature, one can posit therefore that supply chain power enables firms to reduce inventory risk. Better inventory control, in turn, can alleviate firm-level external financing constraints. Based on the above discussion, we formulate the following hypothesis:

Hypothesis 1: Supply chain power reduces inventory-related risk for firms more reliant on supply chain management. Better inventory management, in turn, leads to lower cost of external debt financing for such firms.

To empirically capture the firm's inventory management efficiency and to test hypothesis (1), we use the signal-to-noise ratio of inventory, i.e., the level of desired inventory (signal) relative to the uncertainty associated with achieving the desired level (noise). We measure signal as the average level of inventory in the last three years and the noise as the volatility (standard deviation) of inventory over the last three years. We use quarterly Compustat data to calculate both the signal and noise measures. The signal-to-noise ratio is then calculated as the ratio of the historical average inventory level over the volatility of historical inventory. The measure thus captures the stability of inventory management. We also calculate the signal-tonoise ratio for more disaggregated level of inventories, i.e., finished good, work-in-progress, 
and raw materials. ${ }^{36}$

\subsection{Estimation Strategy}

To empirically identify the significance of the above mechanism, we follow the following regression framework (Judd and Kenny, 1981; James and Brett, 1984; Baron and Kenny, 1986):

$$
\begin{aligned}
\operatorname{LSPREAD}_{\text {lijt }} & =\alpha+\beta \cdot S C P_{i j t}+\kappa \cdot C_{i j t}+W^{\prime} \delta+\mu_{j}+v_{t}+\varepsilon_{\text {lijt }} \\
C_{i j t} & =\omega+\phi S C P_{i j t}+W^{\prime} \gamma+\mu_{j}+v_{t}+\varepsilon_{i j t}
\end{aligned}
$$

where $l$ indexes a loan, $i$ indexes a firm, $j$ indexes an industry, and $t$ refers to time. $L S P R E A D_{l i j t}$ is defined as $\log$ (All-in-Drawn), $S C P_{i j t}$ is the measure of supply-chain power, $C_{i j t}$ is a specific channel in question, and $W$ is the set of various firm- and loan-specific control variables. Empirically, equation (9) captures the direct effect of supply-chain power on the firm-level channels and equation (8) decomposes the baseline effect of $S C P_{i j t}$ on loan spread into the channel effect and the direct effect of $S C P_{i j t}$ independent of a channel. By plugging (9) into (8), we get:

$$
\begin{aligned}
\operatorname{LSPREAD} D_{\text {lijt }}= & \alpha+\kappa \cdot \omega+(\beta+\kappa \cdot \phi) S C P_{i j t} \\
& +W^{\prime}(\kappa \cdot \gamma+\delta)+(1+\kappa)\left(\mu_{j}+v_{t}\right)+\kappa \cdot \varepsilon_{i j t}+\varepsilon_{l i j t} \\
= & \alpha^{*}+\beta^{*} S C P_{i j t}+W^{\prime} \delta^{*}+\vartheta_{i}^{*}+\epsilon_{l i j t}^{*}
\end{aligned}
$$

where $\alpha^{*}=\alpha+\kappa . \omega, \beta^{*}=\beta+\kappa . \phi, \delta^{*}=\delta+\kappa \cdot \gamma, \vartheta_{i}^{*}=(1+\kappa)\left(\mu_{j}+v_{t}\right)$ and $\epsilon_{l i j t}^{*}=\kappa . \epsilon_{i j t}+\varepsilon_{\text {lijt }}$. In equation (10), $\beta^{*}$ is the same as the effect of $S C P_{i j t}$ in the baseline model. However, the decomposition in equation (10) shows that $\kappa . \phi$ of the effect is channeled through the measure $C_{i j t}$ and $\beta$ is the remaining effect of $S C P_{i j t}$ on loan spread. To estimate these parameters separately, we estimate models (8) and (9) simultaneously by means of seemingly unrelated regressions.

\subsection{ESTIMATION RESULTS}

Panels A and B of Table 15 show the unconditional mean differences for inventory management efficiency (INVMGT) and various loan-contract terms. It is obvious from panel A that

\footnotetext{
${ }^{36}$ We report our results using total investory signal-to-noise ratio while the results are similar using other definitions of inventory.
} 
high-SCP firms are more efficient in their inventory management than low-SCP firms suggesting that supply-chain power is positively associated with its inventory control efficiency. In panel $\mathrm{B}$, the table shows the mean differences in various price and non-price loan-contract terms between high and low levels of inventory management efficiency measure. Overall, the summary statistics in the panel show that firms with higher level of inventory-management efficiency pay lower spreads on their loans than firms at the lower end of the inventory efficiency spectrum. The univariate results reported in Table 15 suggest that the supply-chain power of a firm is associated with lower inventory risk which, in turn, leads to lower loan spreads for the firm.

Table 15 is about here

Panel C of Table 15 shows the decomposition of the effect of supply-chain power on the cost of bank loans by estimating regression models (8) and (9) simultaneously in a seemingly unrelated regression. We first report the baseline effect of supply-chain power on the cost of bank loans, captured by the $\beta^{*}$ in model (10). We then report the effect of supply-chain power on the inventory control efficiency itself, captured by the $\phi$ coefficient in model (9). Finally, we decompose the effect of supply-chain power using model (8) into a direct $(\beta)$ and an indirect effect via inventory control efficiency $(\kappa \times \phi)$ on the loan spread. The results show that supply-chain power increases inventory-management efficiency, conditional on other firm- and loan-specific controls. Moreover, consistent with the extant accounting and finance literature, the results in specifications (3) and (6) show that lower inventory risk reduces spreads. Finally, the decomposition analysis of the overall effect of supply-chain power into direct and indirect effects via a channel (reported in specifications (3) and (6)) suggests that the direct effect of supply-chain power on the cost of bank loans $(\beta)$ is always negative and statistically significant at the $1 \%$ level. Moreover, the indirect effects, captured by $\kappa \times \phi$, are also negative. However, controlling for inventory management efficiency, the direct effect of supply-chain power declines by $13.42 \%\left(\frac{-0.216-(-0.187)}{0.216} \times 100\right)$ between specifications 1 and 3 . These results suggest that part of the overall effect of supply-chain power on the cost of bank loans is explained by the inventory risk channel. Overall, the results in Table 15 suggest that supply chain power matters for credit risk; it enables a firm to achieve a greater level of efficiency in its inventory management which, in turn, leads to an elevated level of loan-market access for the firm. 


\section{CONCLUSION}

Fierce global competition, shorter product life-cycles, and heightened consumer expectations have been constantly pushing firms to improve efficiencies in order to remain competitive in the global marketplace. One source of inefficiency lies in the network linking suppliers and customers. Hence, firms have been increasingly more likely to adopt supply chain management techniques over the last three decades. However in the last few years, a significant number of global political events (Brexit, tariff wars, and trade treaty renegotiations) have increased the risk that firms will need to drastically restructure their supply chains. This paper provides a comprehensive analysis on how a firm's economic links with its suppliers affect its provisions for external debt financing.

Specifically, we provide granular-level evidence, using a comprehensive set of price and non-price bank-loan contract terms, that the supply chain power of a firm eases the provisions of bank financing, resulting in a lower spread, higher loan amounts, longer maturity, less collateral, fewer restrictive covenants, and a higher likelihood of syndication and relationship-based transactions. We show that these results are robust to controlling for product-market competition. We also show that supply chain power enables the firm to achieve a greater level of control over its inventory management. Overall, the supply chain induced effect in these real activities translates into an elevated level of debt market access for firms more reliant on these types of production arrangements.

These results suggest that from the perspective of a unique financial stakeholder of the firm, i.e., the bank, upstream (supply-side) interactions in the chain of business activities are at least as important as downstream (demand-side) interactions in determining a firm's debt financing capacity. Our results shed light on the complex interplay of forces that determine why some firms are financially constrained while others are not. Finally, we argue that the key to understanding the origins of financing capacity of firms should not be limited to demand-side attributes, but should naturally be extended to supply chain related interactions of firms. 


\section{REFERENCES}

Aivazian, V., Callen, J., 1980. Corporate Leverage and Growth: The Game Theoretic Issues. Journal of Financial Economics 8, 379-399.

Aivazian, V., Qiu, J., Rahaman, M., 2015. Bank Loan Contracting and Corporate Diversification: Does Organizational Structure Matter to Lenders?. Journal of Financial Intermediation 24, 252-282.

Ak, B. K., Patatoukas, P. N., 2016. Customer-Base Concentration and Inventory Efficiencies: Evidence from the manufacturing sector. Production and Operations Management 25, 258-272.

Alexopoulos, M., Cohen, J., 2009. Uncertain Times, Uncertain Measures. Working paper, University of Toronto.

Altman, E., 1968. Financial Ratios, Discriminant Analysis, and the Prediction of Corporate Bankruptcy. Journal of Finance 23, 589-609.

Atanasov, V., Black, B., 2016. Shock-based Causal Inference in Corporate Finance and Accounting Research. Critical Finance Review 5, 207-304.

Baker, S., Bloom, N., Davis, S., 2016. Measuring Economic Policy Uncertainty. Quarterly Journal of Economics 1, 1593-1636.

Banerjee, S., Dasgupta, S., Kim, Y., 2008. Buyer-Supplier Relationships and the Stakeholder Theory of Capital Structure. Journal of Finance 63, 2507-2552.

Barclay, M., Marx, M., Smith, C., 2003. The Joint Determination of Leverage and Maturity. Journal of Corporate Finance 9, 179-167.

Barclay, M., Smith, C., 1995. The Maturity Structure of Corporate Debt. Journal of Finance 50, 609-631.

Barker. A., Campbell, P., 2018. Honda Faces the Real cost of Brexit in a Former Spitfire Plant. Financial Times, June 26.

Baron, R., Kenny, D., 1986. The Moderator-Mediator Variable Distinction in Social Psychological Research: Conceptual, Strategic, and Statistical Considerations. Journal of Personality and Social Psychology 51, 1173-1182.

Beatty, A., Ramesh, K., Weber, J., 2002. The Importance of Accounting Changes in Debt Contracts: The Cost of Flexibility in Covenant Calculations. Journal of Accounting and Economics 33, 205-227.

Belo, F., Lin, X., 2012. The Inventory Growth Spread. Review of Financial Studies 25, 278-313.

Benmelech, E., Bergman, N., Seru, A., 2015. Financing Labor. Available: https://papers . ssrn. com/sol3/papers. cfm?abstract_id=2608189

Berg, T., Saunders, A., Steffen, S., 2016. The Total Cost of Corporate Borrowing in the Loan Market: Don't Ignore the Fees. Journal of Finance 71, 1357-1392.

Berger, A., Udell, G., 1990. Collateral, Loan Quality and Bank Risk. Journal of Monetary Economics 25, 21-42.

Berger, A., Udell, G., 1992. Some Evidence on the Empirical Significance of Credit Rationing. 
Journal of Political Economy 100, 1047-1077.

Bernard, D., 2016. Is the Risk of Product Market Predation a Cost of Disclosure? Journal of Accounting and Economics 62, 305-325.

Bharath, S., Dahiya, S., Saunders, A., Srinivasan, A., 2011. Lending Relationships and Loan Contract Terms. Review of Financial Studies 24, 1141-1203.

Bharath, S., Shumway, T., 2008. Forecasting Default with the Merton Distance to Default Model. Review of Financial Studies 21, 1339-1369.

Billett, M., Flannery, M., Garfinkel, J., 2006. Are Bank Loans Special? Evidence on the PostAnnouncement Performance of Bank Borrowers. Journal of Financial and Quantitative Analysis 41, 733-751.

Boissay, F., Gropp, R., 2013. Payment Defaults and Interfirm Liquidity Provision. Review of Finance 17, 1-42.

Boyarchenko, N., Costello, A., 2015. Counterparty Risk in Material Supply Contracts. Federal Reserve Bank of New York, Staff Reports, No. 694.

Brunnermeier, K., Pedersen, L., 2009. Market Liquidity and Funding Liquidity. Review of Financial Studies 22, 2201-2238.

Cachon, G.P., 2004. The Allocation of Inventory Risk in a Supply Chain: Push, Pull, and Advance-Purchase Discount Contracts. Management Science 50(2), 222-238.

Campbell, T., Kracaw, W., 1980. Information Production, Market Signaling, and the Theory of Financial Intermediation. Journal of Finance 35, 863-882.

Campello, M., Gao, J., 2017. Customer Concentration and Loan Contract Terms. Journal of Financial Economics 123, 108-136.

Chen, L., Lesmond, D., Wei, J., 2007. Corporate Yield Spreads and Bond Liquidity. Journal of Finance 62, 119-149.

Chopra, S., Sodhi, M.S., 2004. Managing Risk To Avoid Supply-Chain Breakdown. MIT Sloan Management Review 46(1), 53-61.

Chu, Y., 2012. Optimal Capital Structure, Bargaining, and the Supplier Market Structure. Journal of Financial Economics 106, 411-426.

Coase, R., 2006. The Conduct of Economics: The Example of Fisher Body and General Motors. Journal of Economics \& Management Strategy 15(2), 255-278.

Costello, A., 2013. Mitigating Incentive Conflicts in Inter-firm Relationships: Evidence from Long-term Supply Contracts. Journal of Accounting and Economics 56, 19-39.

Costello, A., 2018. Credit Market Disruptions and Liquidity Spillover Effects in the Supply Chain. Available: https://papers.ssrn.com/sol3/papers.cfm?abstract_id= 3258029

Deloitte Consulting LLP, 2013. Deloitte Survey: Executives Face Growing Threats to Their Supply Chains. Available: http://www.deloitte.com/us/supplychainrisksurvey

Demerjian, P., 2017. Uncertainty and Debt Covenants. Review of Accounting Studies 22, 11561197.

Demerjian, P., Owens, E., 2016. Measuring the Probability of Financial Covenant Violation in Private Debt Contracts. Journal of Accounting and Economics 61, 433-447. 
Deming, W., 1986. Out of the Crisis. Cambridge, MA: MIT Press.

Demiroglu, C., James, C., 2010. The Information Content of Bank Loan Covenants. Review of Financial Studies 23, 3700-3737.

Diamond, D., 1984. Financial Intermediation and Delegated Monitoring. Review of Economic Studies 51, 393-414.

Dong, L., Tomlin, B., 2012. Managing Disruption Risk: The Interplay Between Operation and Insurance. Management Science 58, 1898-1915.

Drucker, S., Puri, M., 2005. On the Benefits of Concurrent Lending and Underwriting. Journal of Finance 60, 2763-2799.

Duchin, R., 2010. Cash Holdings and Corporate Diversification. Journal of Finance 65, 955992.

Feenstra, R., 1996. U.S. Imports, 1972-1994: Data and Concordances. NBER Working Paper No. 5515.

Feenstra, R., Romalis, J., Schott, P., 2002. U.S. Import, Exports, and Tariff Data, 1989-2001. NBER Working Paper No. 9387.

Forbes, 2015. Insuring Against Supply Chain Risks. Logistics \& Transportation, September 8. Available: http://www.forbes.com/sites/stevebanker/2015/09/08/ insuring-against-supply-chain-risks/

Gande, A., Saunders, A., 2012. Are Banks Still Special When There is a Secondary Market for Loans? Journal of Finance 67, 1649-1684.

Gaspar, J., Massa, M., 2006, Idiosyncratic Volatility and Product Market Competition. Journal of Business 79, 3125-3152.

Graham, J., Li, S., Qiu, J., 2008. Corporate Misreporting and Bank Loan Contracting. Journal of Financial Economics 88, 44-61.

Guariglia, A., 2008. Internal Financial Constraints, External Financial Constraints, and Investment Choice: Evidence from a Panel of UK firms. Journal of Banking and Finance 32, 1795-1809.

Hart, O., Moore, J., 1994. A Theory of Debt Based on the Inalienability of Human Capital. Quarterly Journal of Economics 109, 841-879.

Hausman, J., 1978. Specification Tests in Econometrics. Econometrica 46, 1251-1271.

He, Z., Xiong, W., 2012. Rollover Risk and Credit Risk. Journal of Finance 67, 391-430.

Hendricks, K., Singhal, V., 2005. An Empirical Analysis of the Effect of Supply Chain Disruptions on Long-Run Stock Price Performance and Equity Risk of the Firm. Production and Operations Management 14, 35-52.

Hennessy, C., Livdan, D., 2009. Debt, Bargaining, and Credibility in Firm-Supplier Relationships. Journal of Financial Economics 93, 382-399.

Hertzel, M., Li, Z., Officer, M., Rodgers, K., 2008. Inter-firm Linkages and the Wealth Effects of Financial Distress Along the Supply Chain. Journal of Financial Economics 87, 374-387.

Hoberg, G., Phillips, G., 2010. Real and Financial Industry Booms and Busts. Journal of Finance $65,45-86$.

Hoberg, G., Phillips, G., Prabhala, N., 2014. Product Market Threats, Payouts, and Financial 
Flexibility. Journal of Finance 69, 293-324.

Hou, K., Robinson, D., 2006. Industry Concentration and Average Stock Returns. Journal of Finance 61, 1927-1956.

Houston, J., Lin, C., Zhu, Z., 2016. The Financial Implications of Supply Chain Changes. Management Science 62, 2520-2542.

Hu, X., Schiantarelli, F., 1998. Investment and Capital Market Imperfections: A Switching Regression Approach Using U.S. Firm Panel Data. Review of Economics and Statistics 80, 466-479.

Hui, K., Klasa, S., Yeung, P., 2012. Corporate Suppliers and Customers and Accounting Conservatism. Journal of Accounting and Economics 53, 115-135.

James, L., Brett, J., 1984. Mediators, Moderators, and Tests for Mediation. Journal of Applied Psychology 69, 307-321.

Jensen, M., 1986. Agency Cost of Free Cash Flow, Corporate Finance, and Takeovers. American Economic Review 76, 323-329.

Jensen, M., Meckling, W., 1976. Theory of the Firm: Managerial Behavior, Agency Costs and Ownership Structure. Journal of Financial Economics 3, 305-360.

Jones, C., Tuzel, S., 2013. Inventory Investment and the Cost of Capital. Journal of Financial Economics 107, 557-579.

Judd, C., Kenny, D., 1981. Process Analysis Estimating Mediation in Treatment Evaluations. Evaluation Review 5, 602-619.

Kale, J., Shahrur, H., 2007. Corporate Capital Structure and the Characteristics of Suppliers and Customers. Journal of Financial Economics 83, 321-365.

Kim, H., Kung, H., 2017. The asset redeployability channel: How uncertainty affects corporate investment. Review of Financial Studeis, 30(1), 245-280.

Kim, J., 2018. Asset specificity and firm value: Evidence from mergers. Journal of Corporate Finance, 48, 375-412.

Klein, B., 1998. Hold-up Problem. In P. K. Newman, The New Palgrave Dictionary of Economics and Law (pp. 241-244). New York: Stockton Press.

Klein, B., Crawford, R., Alchian, A., 1978. Vertical Integration, Appropriable Rents, and Competitive Contracting Process. Journal of Law and Economics 21, 297-326.

Kolay, M., Lemmon, M., Tashjian, E., 2015. Spreading the Misery? Sources of Bankruptcy Spillover in the Supply Chain. Available: https://papers.ssrn.com/sol3/papers . cfm?abstract_id=2019733

KPMG, 2011. Current Japanese Real Estate Market 2011. Available: https://www.kpmg . com/Global/en/industry/real-estate/Documents/ current-japenese-real-estate-market-jan-2011.pdf

Krishnan, G., Patatoukas, P.N., Wang, A. Y., 2018. Customer-base Concentration: Implications for Audit Pricing and Quality. Journal of Management Accounting Research, in press. Available: https://doi.org/10.2308/jmar-52040

Larcker, D., Rusticus, T., 2010. On the Use of Instrumental Variables in Accounting Research. Journal of Accounting and Economics 49, 186-205. 
Lai, G., Debo, L., Sycara, K., 2009. Sharing Inventory Risk in Supply Chain: The Implication of Financial Constraint. Omega 37, 811-825.

Lee, K., 2010. Purchase Obligations, Earnings Persistence and Stock Returns. Working paper, University of California, Berkeley.

Lerner, A., 1934. The Concept of Monopoly and the Measurement of Monopoly Power. Review of Economic Studies 1, 157-175.

Li, N., Vasvari, F., Moerman, R., 2016. Dynamic Threshold Values in Earnings-based Covenants. Journal of Accounting and Economics 61, 605-629.

Lian, Y., 2017. Financial Distress and Customer-Supplier Relationships. Journal of Corporate Finance 43, 397-406.

Longstaff, F., Mithal, S., Neis, E., 2005. Corporate Yield Spreads: Default Risk or Liquidity? New Evidence from the Credit Default Swap Market. Journal of Finance 60, 2213-2253.

MacKay, P., Phillips, G., 2005. How Does Industry Affect Firm Financial Structure? Review of Financial Studies 18, 1433-1466.

Maskimovic, V., Titman, S., 1991. Financial Policy and Reputation for Product Quality. Review of Financial Studies 4, 175-200.

Moon, S., Phillips, G., 2017. Outside Purchase Contracts and Firm Capital Structure. Available: https: //papers.ssrn. com/sol3/papers. cfm?abstract_id=2373793

Morellec, E., Nikolov, B., Zucchi, F., 2013. Cash Holdings and Competition. Available: https : //infoscience.epfl.ch/record/188146/

Nagarajan, M., Bassok, Y., 2008. A Bargaining Framework in Supply Chains: The Assembly Problem. Management Science 54, 1482-1996.

Nagarajan, M., Sosic, G., 2009. Coalition Stability in Assembly Models. Operations Research 57, 131-145.

Norrman, A., Jansson, U., 2004. Ericsson's Proactive Supply Chain Risk Management Approach after a Serious Sub-supplier Accident. International Journal of Physical Distribution \& Logistics Management 4, 434-456.

Nunn, N., 2007. Relationship-specificity, Incomplete Contract and the Pattern of Trade. Quarterly Journal of Economics 122, 569-600.

Ohlson, J., 1980. Financial Ratios and the Probabilistic Prediction of Bankruptcy. Journal of Accounting Research 18, 109-131.

Patatoukas, P. N., 2012. Customer-base Concentration: Implications for Firm Performance and Capital Markets. The Accounting Review 87, 363-392.

Peek, J., Rosengren, E., 2000. Collateral Damage: Effects of the Japanese Real Estate Collapse on Credit Availability and Real Activity in the United States. American Economic Review 90, 30-45.

Porter, M., 1985. Competitive Advantage. New York: The Free Press.

PricewaterhouseCoopers Inc, 2014. Managing Risk: Supply Chain Finance. Available: http: //www.pwc.com/us/en/risk-management/assets/supply-chain-finance.pdf

Rogerson, W., 1992. Contractual Solutions to the Hold-Up Problem. Review of Economic Studies 4, 777-793. 
Schott, P., 2008. The Relative Sophistication of Chinese Export. Economic Policy, January 2008, 5-49.

Shleifer, A., Vishny, R., 1992. Liquidation Values and Debt Capacity: A Market Equilibrium Approach. Journal of Finance 47, 1343-1366.

Sloan, R., 1996. Do Stock Prices Fully Reflect Information in Accruals and Cash Flows about Future Earnings? Accounting Review 71, 289-315.

Smith, C., Warner, J., 1979. On Financial Contracting: An Analysis of Bond Covenants. Journal of Financial Economics 7, 117-161.

Standard \& Poor's, 2011. A Guide to the Loan Market. Available: https : //www . lcdcomps . $\mathrm{com} / \mathrm{d} / \mathrm{pdf} /$ LoanMarketguide.pdf

Thomas, J., Zhang, H., 2002. Inventory Changes and Future Returns. Review of Accounting Studies 7, 163-187.

Titman, S., 1984. The Effect of Capital Structure on Firm Liquidation Decision. Journal of Financial Economics 13, 137-151.

Valta, P., 2012. Competition and the Cost of Debt. Journal of Financial Economics 105, 661682.

Whited, T., 1992. Debt, Liquidity Constraints, and Corporate Investment: Evidence From Panel Data. Journal of Finance 47, 1425-60.

Williams, R., 2012. Vertical Firm Boundaries: Supplier-Customer Contracts and Vertical Integration. Finance Dissertations, Paper 20, Georgia State University.

Williamson, O., 1979. Transaction Cost Economics: The Governance of Contractual Relations. Journal of Law and Economics 22, 233-261.

Williamson, O., 1985. The Economic Institutions of Capitalism. New York: The Free Press.

Wooldridge, J., 2002. Econometric Analysis of Cross Section and Panel Data. Cambridge, MA: MIT Press.

World Economic Forum, 2013. Building Resilience in Supply Chains. An Initiative of the Risk Response Network in collaboration with Accenture, pp. 1-44. Available: http://www3. weforum.org/docs/WEF \_RRN\_MO\_BuildingResilienceSupplyChains \_Report _2013.pdf

Xu, J., 2012. Profitability and Capital Structure: Evidence from Import Penetration. Journal of Financial Economics 106, 427-446.

Yang, S., Birge, J., 2017. Trade Credit, Risk Sharing, and Inventory Financing Portfolios. Management Science 64, 3469-3970. 
Table 1: Sample firms and loans: 1990-2012

This table describes our matched loan sample for the period 1990-2012 for which both the loan spread information and the firm-level supply chain power (SCP) measure are available. Panel A reports the number of firms and loans as well as the loan-to-firm ratio over the years. Panel B reports loan types and primary purposes. HSCP refers to high level of power the firm has relative to its suppliers in the supply chain. A firm is defined as having high supply-chain power if the firm-level SCP measure is above the $75^{\text {th }}$ percentile of its sample distribution. LSCP refers to low level of power relative to firms in the supply chain. A firm is defined as less powerful if the firm-level $S C P$ measure is below the $25^{\text {th }}$ percentile of its sample distribution.

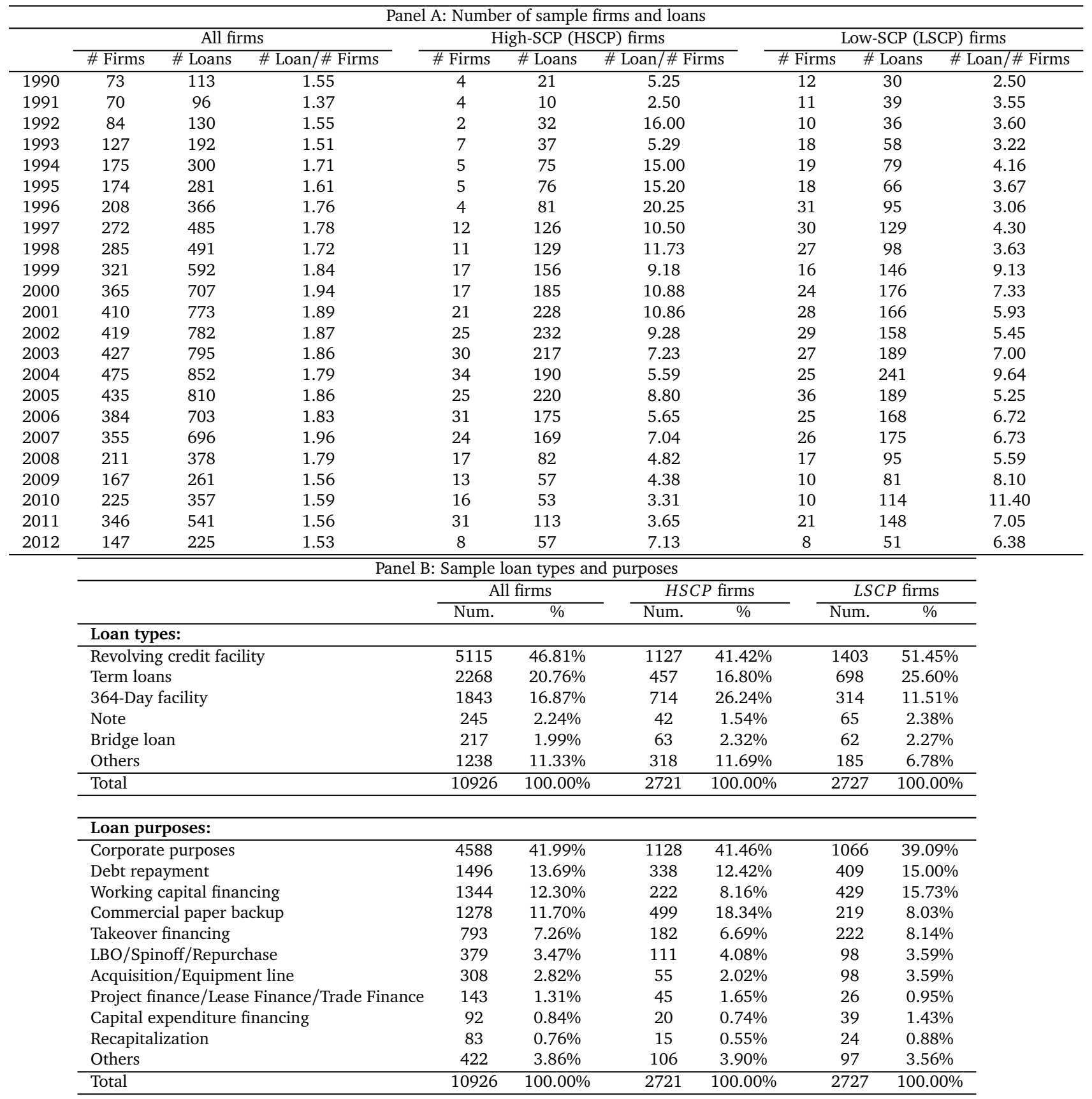




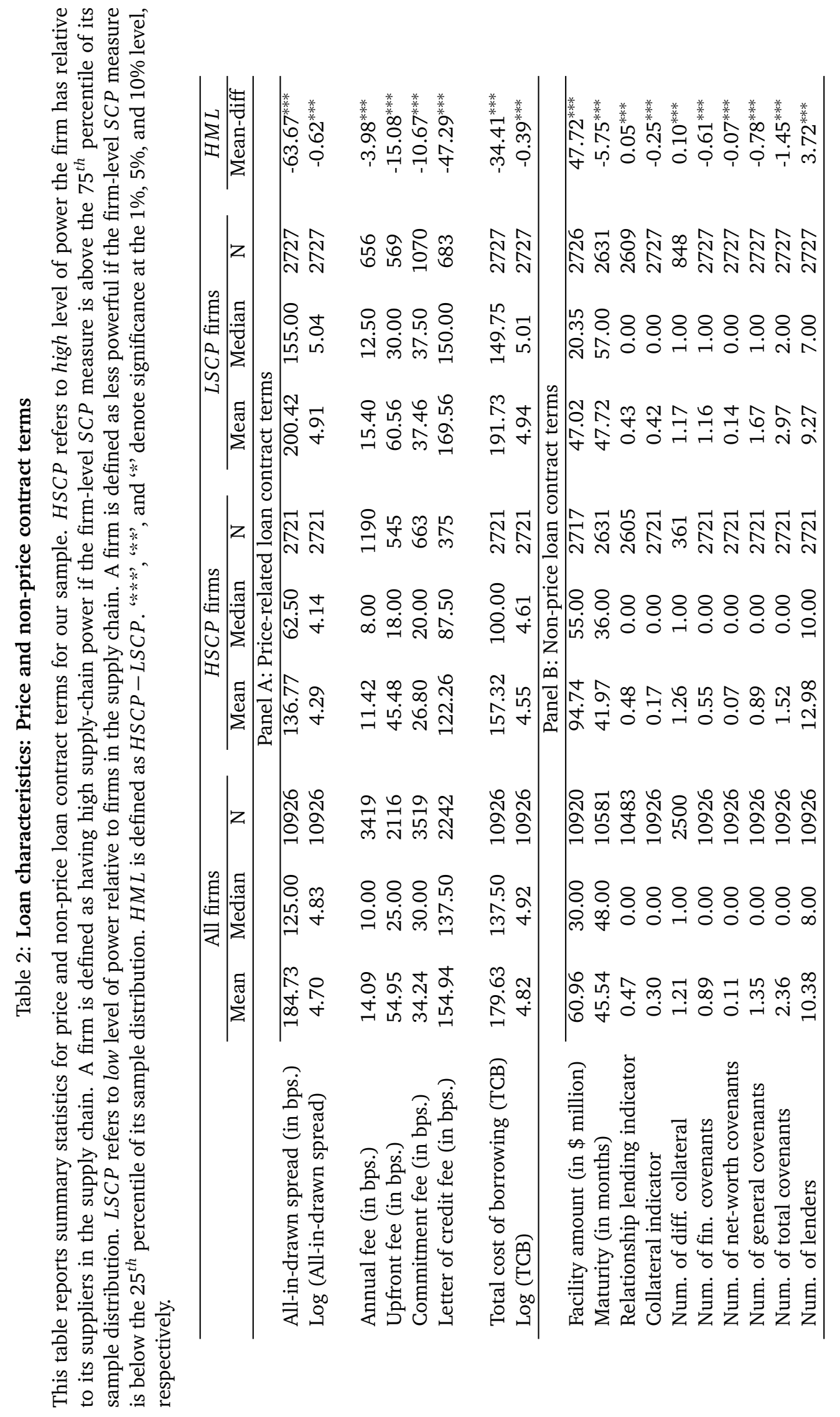




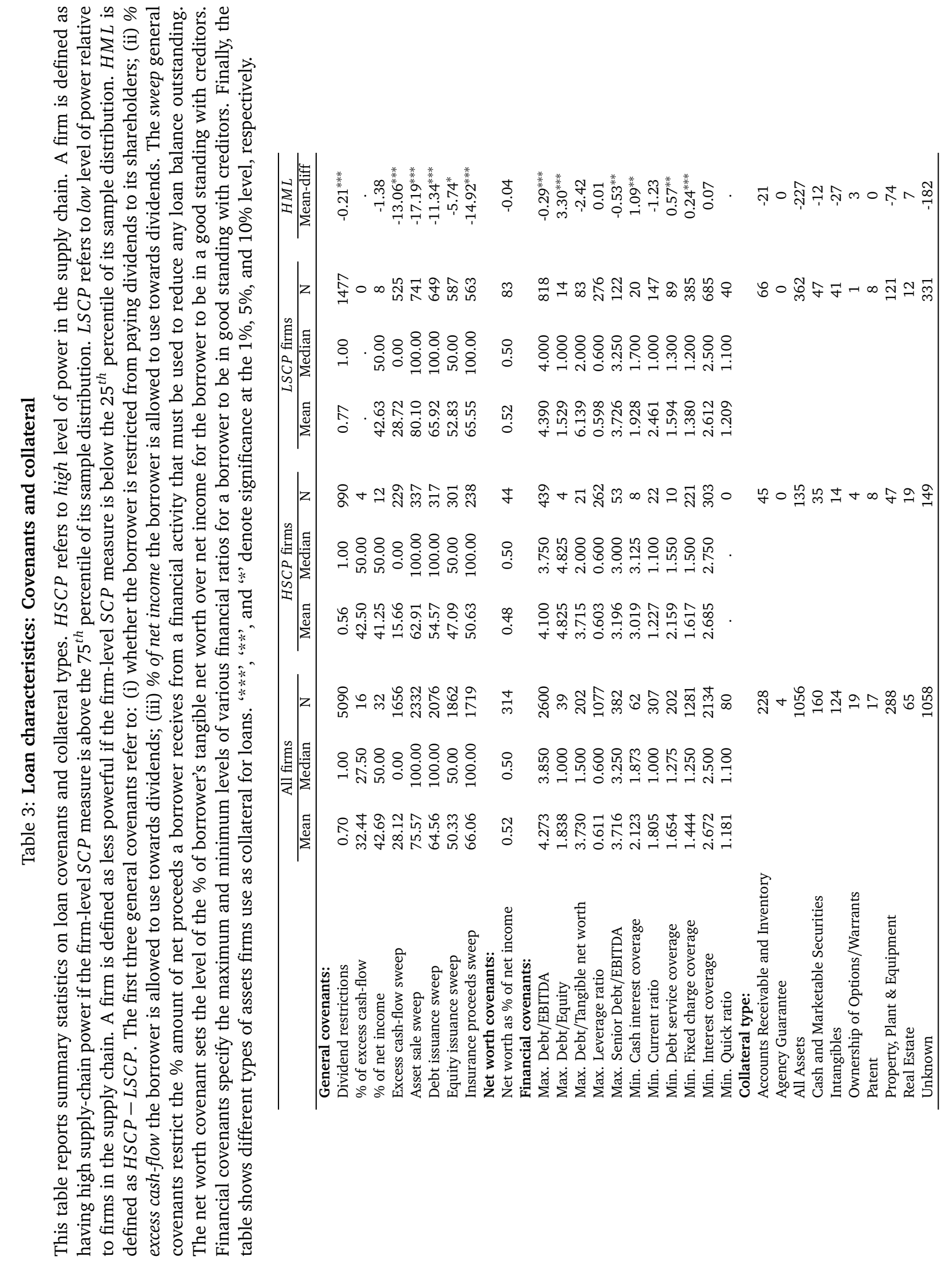




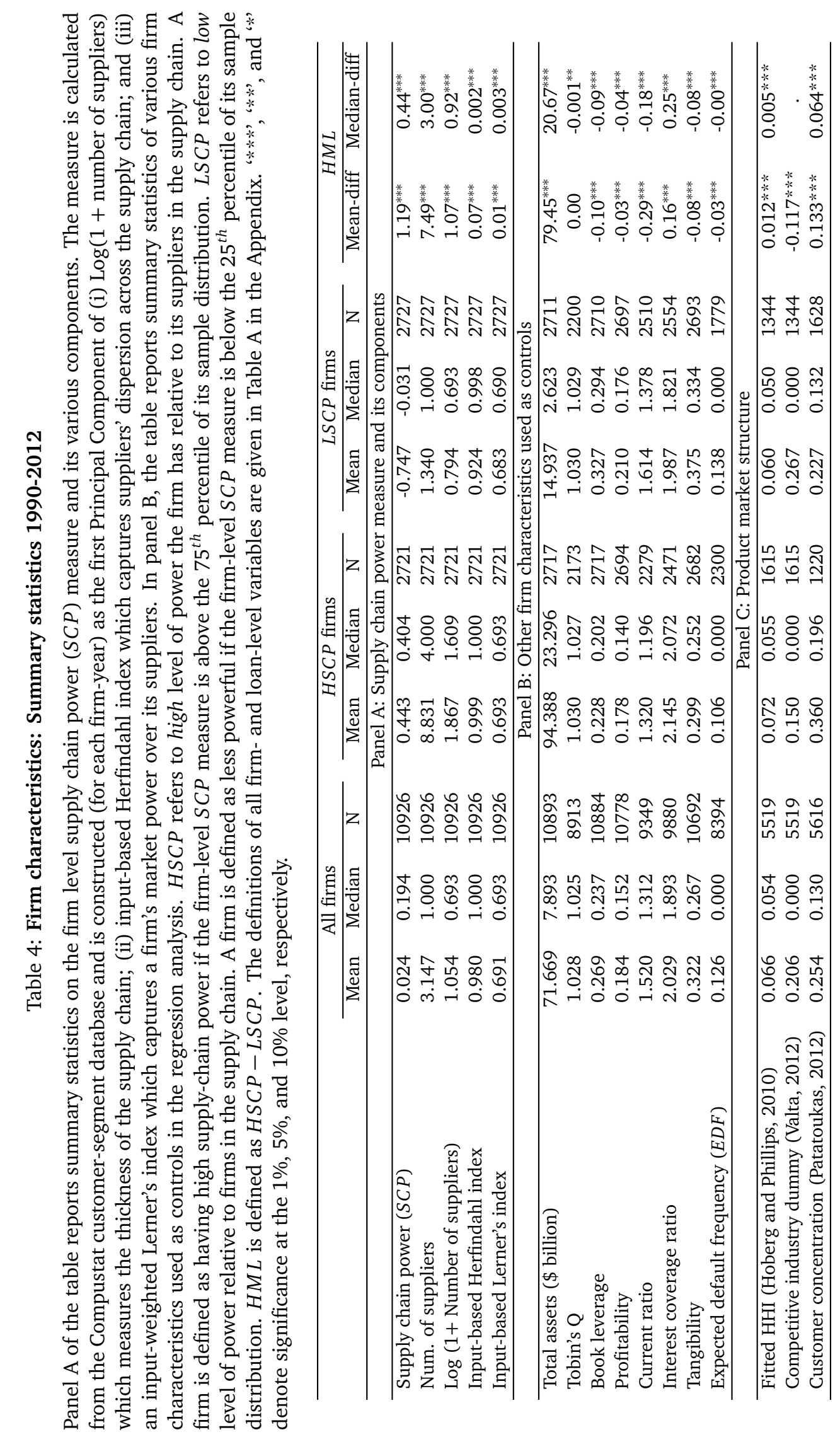


Table 5: Supply chain power and loan spread: Unconditional OLS

This table reports coefficients from OLS regressions on the effects of supply chain power on the cost of bank loans. Panel A provides the baseline unconditional regression estimates while panel B controls for product-market competition measure from Hoberg and Phillips (2010). The definitions of all firm- and loan-level variables are given in Table A in the Appendix. t-statistics (with standard errors clustered at the firm and deal level) are given in parentheses. '***', '**', and '*' denote significance at the $1 \%, 5 \%$, and $10 \%$ level, respectively.

\begin{tabular}{|c|c|c|c|c|c|c|c|c|}
\hline & \multicolumn{4}{|c|}{ Log(All-in-Drawn) } & \multicolumn{4}{|c|}{$\log (\mathrm{TCB})$} \\
\hline & [1] & {$[2]$} & {$[3]$} & [4] & [5] & [6] & {$[7$} & [8] \\
\hline & \multicolumn{8}{|c|}{ Panel A: Baseline OLS estimation } \\
\hline Supply chain power (SCP) & $\begin{array}{c}-0.091 * * * \\
{[-5.49]}\end{array}$ & & & & $\begin{array}{c}-0.078 * * * \\
{[-4.86]}\end{array}$ & & & \\
\hline Log(Num. of suppliers) & & $\begin{array}{c}-0.400 * * * \\
{[-20.49]}\end{array}$ & & & & $\begin{array}{c}-0.365 * * * \\
{[-18.79]}\end{array}$ & & \\
\hline Supply chain dispersion & & & $\begin{array}{c}-0.530 * * * \\
{[-3.15]}\end{array}$ & & & & $\begin{array}{c}-0.475^{* * *} \\
{[-2.91]}\end{array}$ & \\
\hline Supply chain Lerner's Index & & & & $\begin{array}{c}-4.361 * * * \\
{[-3.41]}\end{array}$ & & & & $\begin{array}{c}-3.883 * * * \\
{[-3.31]}\end{array}$ \\
\hline Constant & $\begin{array}{c}4.377 * * * \\
{[34.49]}\end{array}$ & $\begin{array}{c}4.607 * * * \\
{[38.78]}\end{array}$ & $\begin{array}{c}5.577 * * * \\
{[20.45]}\end{array}$ & $\begin{array}{c}7.412 * * * \\
{[8.23]}\end{array}$ & $\begin{array}{c}3.954 * * * \\
{[30.67]}\end{array}$ & $\begin{array}{c}4.164 * * * \\
{[34.22]}\end{array}$ & $\begin{array}{c}5.327^{* * *} \\
{[19.42]}\end{array}$ & $\begin{array}{c}6.657 * * * \\
{[8.05]}\end{array}$ \\
\hline Industry \& year fixed effects & Yes & Yes & Yes & Yes & Yes & Yes & Yes & Yes \\
\hline $\mathrm{N}$ & 10926 & 10926 & 10926 & 10926 & 10926 & 10926 & 10926 & 10926 \\
\hline \multirow[t]{2}{*}{$R^{2}$} & 0.12 & 0.16 & 0.13 & 0.11 & 0.11 & 0.14 & 0.13 & 0.10 \\
\hline & \multicolumn{8}{|c|}{ Panel B: Controlling for product-market competition } \\
\hline Supply chain power (SCP) & $\begin{array}{c}-0.160 * * * \\
{[-7.95]}\end{array}$ & & & & $\begin{array}{c}-0.154 * * * \\
{[-8.02]}\end{array}$ & & & \\
\hline Log(Num. of suppliers) & & $\begin{array}{c}-0.433 * * * \\
{[-16.93]}\end{array}$ & & & & $\begin{array}{c}-0.393 * * * \\
{[-15.60]}\end{array}$ & & \\
\hline Supply chain dispersion & & & $\begin{array}{c}-0.737 * * * \\
{[-3.33]}\end{array}$ & & & & $\begin{array}{c}-0.699 * * * \\
{[-3.33]}\end{array}$ & \\
\hline Supply chain Lerner's Index & & & & $\begin{array}{c}-5.581 * * * \\
{[-2.40]}\end{array}$ & & & & $\begin{array}{c}-5.593 * * * \\
{[-2.60]}\end{array}$ \\
\hline HHI & $\begin{array}{c}-2.779 * * * \\
{[-4.29]}\end{array}$ & $\begin{array}{c}-1.513 * * * \\
{[-2.71]}\end{array}$ & $\begin{array}{c}-2.472 * * * \\
{[-2.81]}\end{array}$ & $\begin{array}{c}-2.962 * * * \\
{[-4.49]}\end{array}$ & $\begin{array}{c}-2.429 * * * \\
{[-3.86]}\end{array}$ & $\begin{array}{c}-1.266^{* *} \\
{[-2.32]}\end{array}$ & $\begin{array}{c}-2.295^{* * *} \\
{[-2.68]}\end{array}$ & $\begin{array}{c}-2.599 * * * \\
{[-4.06]}\end{array}$ \\
\hline Constant & $\begin{array}{c}5.248 * * * \\
{[23.31]}\end{array}$ & $\begin{array}{c}5.464 * * * \\
{[26.74]}\end{array}$ & $\begin{array}{c}6.218 * * * \\
{[12.92]}\end{array}$ & $\begin{array}{c}9.101 * * * \\
{[5.62]}\end{array}$ & $\begin{array}{c}4.928 * * * \\
{[21.51]}\end{array}$ & $\begin{array}{c}5.089 * * * \\
{[41.23]}\end{array}$ & $\begin{array}{c}6.826 * * * \\
{[13.31]}\end{array}$ & $\begin{array}{c}8.790 * * * \\
{[5.84]}\end{array}$ \\
\hline Industry \& year fixed effects & Yes & Yes & Yes & Yes & Yes & Yes & Yes & Yes \\
\hline $\mathrm{N}$ & 5695 & 5695 & 5695 & 5695 & 5695 & 5695 & 5695 & 5695 \\
\hline $\mathrm{R}^{2}$ & 0.10 & 0.15 & 0.10 & 0.09 & 0.09 & 0.13 & 0.09 & 0.08 \\
\hline
\end{tabular}


Table 6: Supply chain power and loan spread: Conditional OLS

This table reports coefficients from OLS regressions on the effects of supply chain power on the cost of bank loans conditional on firms and loan characteristics and product-market competition. The definitions of all firm- and loan-level variables are given in Table A in the Appendix. t-statistics (with standard errors clustered at the firm and deal level) are given in parentheses. ' $* * \cdots$ ', ' $* *$ ', and ' $*$ ' denote significance at the $1 \%, 5 \%$, and $10 \%$ level, respectively.

\begin{tabular}{|c|c|c|c|c|c|c|}
\hline & \multicolumn{3}{|c|}{ Log(All-in-Drawn) } & \multicolumn{3}{|c|}{ Log(TCB) } \\
\hline & {$[1]$} & [2] & [3] & {$[4]$} & {$[5]$} & [6] \\
\hline Supply chain power (SCP) & $\begin{array}{c}-0.113^{* * * *} \\
{[-7.03]}\end{array}$ & $\begin{array}{c}-0.045 * * * \\
{[-4.37]}\end{array}$ & $\begin{array}{c}-0.057 * \cdots * * \\
{[-3.75]}\end{array}$ & $\begin{array}{c}-0.100 * * * \\
{[-6.67]}\end{array}$ & $\begin{array}{c}-0.043 * * * \\
{[-4.17]}\end{array}$ & $\begin{array}{c}-0.055 * * * \\
{[-3.79]}\end{array}$ \\
\hline HHI & & & $\begin{array}{c}-0.885^{* *} \\
{[-2.27]}\end{array}$ & & & $\begin{array}{c}-0.791^{* * *} \\
{[-2.06]}\end{array}$ \\
\hline Total assets ( $\$$ billion) & $\begin{array}{c}-0.002^{* * * *} \\
{[-3.90]}\end{array}$ & $\begin{array}{c}-0.001 * * * \\
{[-2.82]}\end{array}$ & $\begin{array}{c}-0.001 * * * \\
{[-3.05]}\end{array}$ & $\begin{array}{c}-0.002 * * * \\
{[-2.95]}\end{array}$ & $\begin{array}{l}-0.001 * \\
{[-1.83]}\end{array}$ & $\begin{array}{c}-0.002 * * * \\
{[-3.56]}\end{array}$ \\
\hline Tobin's Q & $\begin{array}{c}-5.970 * * * \\
{[-10.50]}\end{array}$ & $\begin{array}{c}-3.971 * * * \\
{[-9.96]}\end{array}$ & $\begin{array}{c}-0.149 * * * * \\
{[-7.22]}\end{array}$ & $\begin{array}{c}-5.630 * * * \\
{[-9.76]}\end{array}$ & $\begin{array}{c}-5.865 * * * * \\
{[-13.44]}\end{array}$ & $\begin{array}{c}-0.135 * * * \\
{[-6.67]}\end{array}$ \\
\hline Book leverage & $\begin{array}{c}0.719 * * * \\
{[7.68]}\end{array}$ & $\begin{array}{c}0.202^{* * *} \\
{[3.11]}\end{array}$ & $\begin{array}{l}0.160^{*} \\
{[1.85]}\end{array}$ & $\begin{array}{c}0.777^{*} \text { **** } \\
{[8.14]}\end{array}$ & $\begin{array}{c}0.372 * * * * \\
{[5.35]}\end{array}$ & $\begin{array}{l}0.145^{*} \\
{[1.64]}\end{array}$ \\
\hline Profitability & $\begin{array}{c}-0.342^{* * *} \\
{[-2.22]}\end{array}$ & $\begin{array}{l}-0.083 \\
{[-0.91]}\end{array}$ & $\begin{array}{c}-0.295^{* * *} \\
{[-2.29]}\end{array}$ & $\begin{array}{c}-0.304 * * \\
{[-2.07]}\end{array}$ & $\begin{array}{l}0.027 \\
{[0.27]}\end{array}$ & $\begin{array}{c}-0.299 * * * \\
{[-2.38]}\end{array}$ \\
\hline Tangibility & $\begin{array}{c}-0.181 * * \\
{[-2.19]}\end{array}$ & $\begin{array}{l}-0.065 \\
{[-1.13]}\end{array}$ & $\begin{array}{c}-0.150^{*} \\
{[-1.81]}\end{array}$ & $\begin{array}{l}-0.145^{*} \\
{[-1.75]}\end{array}$ & $\begin{array}{l}-0.138^{* * *} \\
{[-2.25]}\end{array}$ & $\begin{array}{l}-0.124 \\
{[-1.53]}\end{array}$ \\
\hline Current ratio & $\begin{array}{c}0.194 * * * \\
{[10.42]}\end{array}$ & $\begin{array}{c}0.076^{* * *} \\
{[5.92]}\end{array}$ & $\begin{array}{c}0.078 * * * \\
{[4.48]}\end{array}$ & $\begin{array}{c}0.171 \text { **** } \\
{[8.95]}\end{array}$ & $\begin{array}{c}0.070 * * * * \\
{[5.14]}\end{array}$ & $\begin{array}{c}0.072 * * * \\
{[3.93]}\end{array}$ \\
\hline Interest coverage ratio & $\begin{array}{c}-0.212^{* * * *} \\
{[-9.48]}\end{array}$ & $\begin{array}{c}-0.177 * * * \\
{[-11.66]}\end{array}$ & $\begin{array}{c}-0.163 * * * * \\
{[-8.04]}\end{array}$ & $\begin{array}{c}-0.204 * * * \\
{[-8.91]}\end{array}$ & $\begin{array}{c}-0.126 * * * * \\
{[-7.77]}\end{array}$ & $\begin{array}{c}-0.154 * * * \\
{[-7.31]}\end{array}$ \\
\hline Expected default frequency (EDF) & $\begin{array}{c}0.602^{* * *} \\
{[11.76]}\end{array}$ & $\begin{array}{c}0.261 * * * \\
{[6.50]}\end{array}$ & $\begin{array}{c}0.274 * * * \\
{[4.43]}\end{array}$ & $\begin{array}{c}0.585^{* * *} \\
{[11.05]}\end{array}$ & $\begin{array}{c}0.347^{* * * *} \\
{[8.36]}\end{array}$ & $\begin{array}{c}0.252^{* \cdots *} \\
{[4.19]}\end{array}$ \\
\hline Loan amount (\$ million) & & $\begin{array}{c}-0.002 * * * * \\
{[-18.28]}\end{array}$ & $\begin{array}{c}-0.003^{* * * *} \\
{[-13.23]}\end{array}$ & & $\begin{array}{c}-0.002 * * * * \\
{[-13.61]}\end{array}$ & $\begin{array}{c}-0.002^{* * *} \\
{[-11.51]}\end{array}$ \\
\hline Loan maturity & & $\begin{array}{c}-0.003 * * * \\
{[-4.99]}\end{array}$ & $\begin{array}{c}-0.004 * \cdots * * \\
{[-4.88]}\end{array}$ & & $\begin{array}{c}-0.004 * * * * \\
{[-7.45]}\end{array}$ & $\begin{array}{c}-0.004 * * * * \\
{[-5.08]}\end{array}$ \\
\hline Collateral dummy & & $\begin{array}{c}0.524 * * * \\
{[23.92]}\end{array}$ & $\begin{array}{c}0.598 * * * \\
{[19.10]}\end{array}$ & & $\begin{array}{c}0.422 * * * * \\
{[18.59]}\end{array}$ & $\begin{array}{c}0.506 * * * * \\
{[16.37]}\end{array}$ \\
\hline Big 3 lender dummy & & $\begin{array}{c}-0.073^{* * *} \\
{[-3.14]}\end{array}$ & $\begin{array}{c}-0.092^{* * *} \\
{[-2.95]}\end{array}$ & & $\begin{array}{c}-0.090 * * * * \\
{[-3.64]}\end{array}$ & $\begin{array}{c}-0.080 * * * \\
{[-2.56]}\end{array}$ \\
\hline Relationship-loan dummy & & $\begin{array}{c}-0.039 * * * \\
{[-2.50]}\end{array}$ & $\begin{array}{l}-0.026 \\
{[-1.19]}\end{array}$ & & $\begin{array}{c}-0.079 * * * * \\
{[-4.63]}\end{array}$ & $\begin{array}{l}-0.022 \\
{[-1.07]}\end{array}$ \\
\hline Constant & $\begin{array}{c}10.637^{* * * *} \\
{[17.44]}\end{array}$ & $\begin{array}{c}11.291 * * * \\
{[24.33]}\end{array}$ & $\begin{array}{c}8.234 * * * \\
{[29.78]}\end{array}$ & $\begin{array}{c}10.233 * * * * \\
{[16.75]}\end{array}$ & $\begin{array}{c}12.868^{* * * *} \\
{[27.41]}\end{array}$ & $\begin{array}{r}4.578^{* \cdots * *} \\
{[13.39]}\end{array}$ \\
\hline Industry \& year fixed effects & Yes & Yes & Yes & Yes & Yes & Yes \\
\hline Loan types and purposes dummies & Yes & Yes & Yes & Yes & Yes & Yes \\
\hline Clustered by firm and deal & Yes & Yes & Yes & Yes & Yes & Yes \\
\hline $\mathrm{N}$ & 7466 & 6956 & 3855 & 7466 & 6956 & 3855 \\
\hline$R^{2}$ & 0.36 & 0.69 & 0.71 & 0.33 & 0.62 & 0.70 \\
\hline Standardized coefficients: & & & & & & \\
\hline SCP & & & $-0.057 * * *$ & & & $-0.056 * * *$ \\
\hline HHI & & & $-0.025 * *$ & & & $-0.026^{* *}$ \\
\hline
\end{tabular}




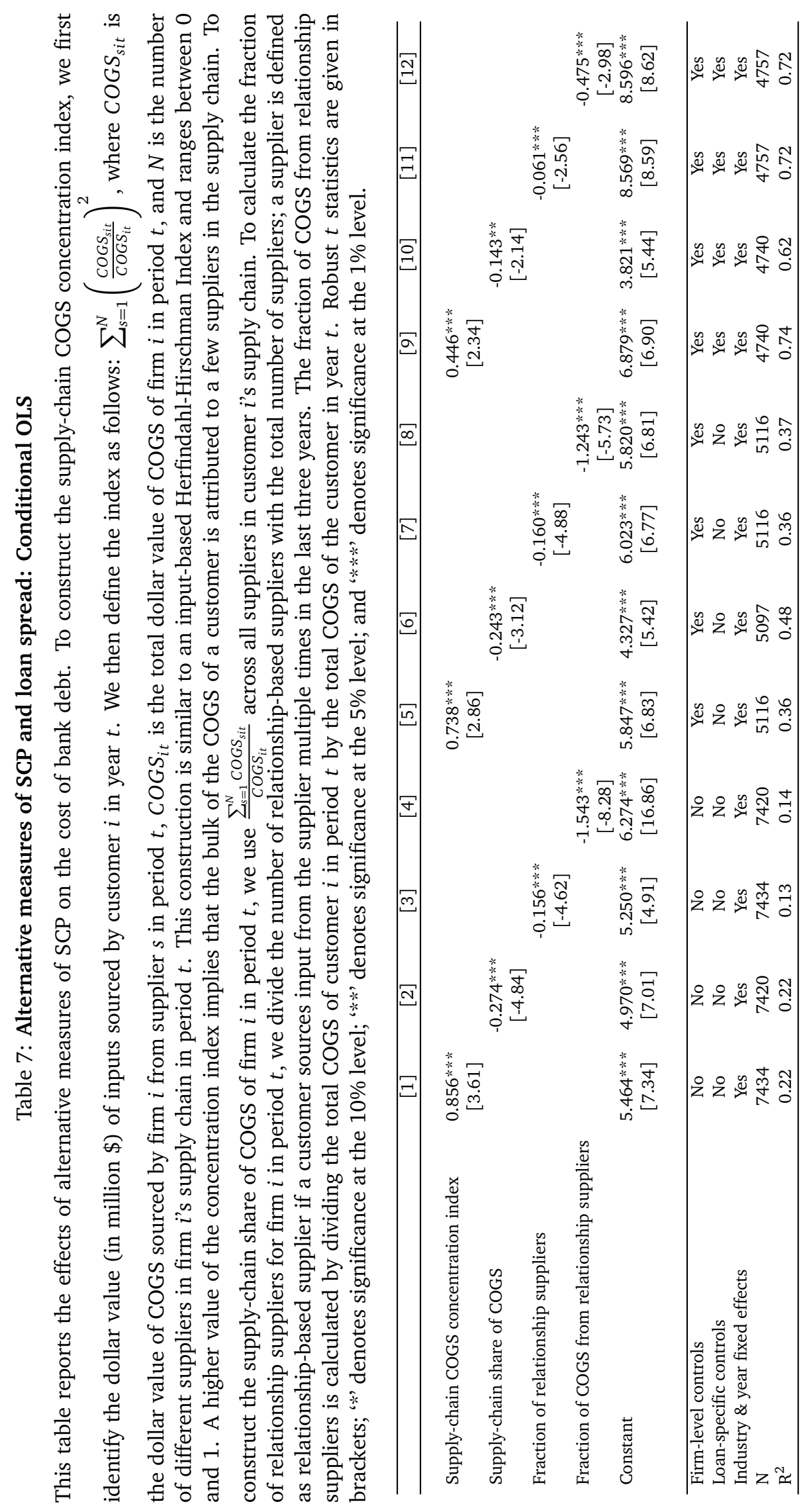


Table 8: Demand- and supply-side market power and the cost of debt

This table reports the estimates of the effects of product-side and supply-side market power on a firm's cost of external debt financing. The product-market power is captured by Hoberg and Phillips's (2010) HHI index and the supply-side power is measured by the SCP variable described in the main text of the paper. t-statistics (with standard errors clustered at the firm and deal level) are given in parentheses. ' $* * *$ ' ' $* *$ ', and ' $*$ ' denote significance at the $1 \%, 5 \%$, and $10 \%$ level, respectively.

\begin{tabular}{|c|c|c|c|c|}
\hline & {$[1]$} & [2] & [3] & [4] \\
\hline$H H I$ effect conditional on $S C P_{H i g h}\left(\beta_{H}\right)$ & $\begin{array}{l}-2.129 * * * \\
{[-3.96]}\end{array}$ & & & \\
\hline$H H I$ effect conditional on $S C P_{\text {Low-High }}\left(\beta_{L}-\beta_{H}\right)$ & $\begin{array}{c}2.186 * * * * \\
{[3.11]}\end{array}$ & & & \\
\hline CUSTCON effect conditional on $S C P_{H i g h}\left(\beta_{H}\right)$ & & $\begin{array}{c}0.03 \\
{[0.51]}\end{array}$ & & \\
\hline CUSTCON effect conditional on $S C P_{\text {Low-High }}\left(\beta_{L}-\beta_{H}\right)$ & & $\begin{array}{l}-0.128 * \\
{[-1.61]}\end{array}$ & & \\
\hline$S C P$ effect conditional on $H_{H} I_{H i g h}\left(\beta_{H}\right)$ & & & $\begin{array}{c}-0.048 * * * * \\
{[-3.06]}\end{array}$ & \\
\hline$S C P$ effect conditionla on $H H I_{\text {Low-High }}\left(\beta_{L}-\beta_{H}\right)$ & & & $\begin{array}{l}-0.080 * * \\
{[-2.31]}\end{array}$ & \\
\hline$S C P$ effect conditional on $C U S T C O N_{H i g h}\left(\beta_{H}\right)$ & & & & $\begin{array}{l}-0.035 * * * \\
{[-2.74]}\end{array}$ \\
\hline$S C P$ effect conditional on CUSTCON $N_{\text {Low-High }}\left(\beta_{L}-\beta_{H}\right)$ & & & & $\begin{array}{l}0.011 \\
{[0.27]}\end{array}$ \\
\hline Firm and loan characteristics & Yes & Yes & Yes & Yes \\
\hline Loan types and purposes dummies & Yes & Yes & Yes & Yes \\
\hline$S C P_{\text {Low }}$ dummy variable & Yes & Yes & No & No \\
\hline$H H I_{\text {Low }}$ dummy variable & No & No & Yes & No \\
\hline CUSTCON $_{\text {Low }}$ dummy variable & No & No & No & Yes \\
\hline$S C P_{\text {Low }} \times$ firm and loan characteristics & Yes & Yes & No & No \\
\hline$H H I_{\text {Low }} \times$ firm and loan characteristics & No & No & Yes & No \\
\hline CUSTCON $_{\text {Low }} \times$ firm and loan characteristics & No & No & No & Yes \\
\hline Industry \& year fixed effects & Yes & Yes & Yes & Yes \\
\hline $\mathrm{N}$ & 3856 & 4146 & 3856 & 4146 \\
\hline $\mathrm{R}^{2}$ & 0.72 & 0.67 & 0.71 & 0.66 \\
\hline
\end{tabular}


Table 9: Supply chain power and loan spread: Instrumental variables (IV) analysis

This table reports coefficients from IV regressions on the effects of supply chain power on the cost of bank loans. The definitions of all firm- and loan-level variables are given in Table A in the Appendix. t-statistics (with standard errors clustered at the firm and deal level) are given in parentheses. ' $* * \cdots$, ' $* \cdots$ ', and ( $*$ ' denote significance at the $1 \%, 5 \%$, and $10 \%$ level, respectively.

\begin{tabular}{|c|c|c|c|c|}
\hline & \multicolumn{2}{|c|}{ IV analysis - I } & \multicolumn{2}{|c|}{ IV analysis - II } \\
\hline & First-stage & Second-stage & First-stage & Second-stage \\
\hline & {$[1]$} & {$[2]$} & {$[3]$} & {$[4]$} \\
\hline Suppliers' geographical dispersion (IV) & $0.031 * * *$ & & & \\
\hline Supply chain minority interest (IV) & & & $\begin{array}{c}-0.739 * * * \\
{[-2.73]}\end{array}$ & \\
\hline Supply chain power (SCP) - IV & & $\begin{array}{c}-0.648 * * * \\
{[-3.13]}\end{array}$ & & $\begin{array}{c}-1.108 * * * \\
{[-5.88]}\end{array}$ \\
\hline Total assets ( $\$$ billion) & $\begin{array}{c}0.003^{* * *} \\
{[3.48]}\end{array}$ & $\begin{array}{l}-0.001 \\
{[-0.74]}\end{array}$ & $\begin{array}{c}0.002^{* * *} \\
{[4.89]}\end{array}$ & $\begin{array}{c}0.001 \\
{[1.56]}\end{array}$ \\
\hline Tobin's Q & $\begin{array}{c}0.004 \\
{[0.10]}\end{array}$ & $\begin{array}{l}-0.167 * * * \\
{[-4.37]}\end{array}$ & $\begin{array}{l}-0.016 \\
{[-0.67]}\end{array}$ & $\begin{array}{c}-0.283^{* * *} \\
{[-8.56]}\end{array}$ \\
\hline Book leverage & $\begin{array}{l}-0.276^{*} \\
{[-1.63]}\end{array}$ & $\begin{array}{l}-0.179 \\
{[-1.06]}\end{array}$ & $\begin{array}{l}-0.071 \\
{[-0.83]}\end{array}$ & $\begin{array}{c}0.547 * * * \\
{[4.50]}\end{array}$ \\
\hline Profitability & $\begin{array}{l}-0.472^{* * *} \\
{[-2.09]}\end{array}$ & $\begin{array}{l}-0.473 * * \\
{[-2.03]}\end{array}$ & $\begin{array}{c}-0.778 * * * \\
{[-5.96]}\end{array}$ & $\begin{array}{c}-1.116^{* * * *} \\
{[-4.63]}\end{array}$ \\
\hline Tangibility & $\begin{array}{l}-0.073 \\
{[-0.42]}\end{array}$ & $\begin{array}{c}0.216 \\
{[1.31]}\end{array}$ & $\begin{array}{c}-0.1 \\
{[-1.12]}\end{array}$ & $\begin{array}{l}-0.239 * * \\
{[-1.90]}\end{array}$ \\
\hline Current ratio & $\begin{array}{c}0.01 \\
{[0.32]}\end{array}$ & $\begin{array}{c}0.097 * * * \\
{[3.16]}\end{array}$ & $\begin{array}{l}-0.019 \\
{[-1.02]}\end{array}$ & $\begin{array}{c}0.078 * * * \\
{[2.92]}\end{array}$ \\
\hline Interest coverage ratio & $\begin{array}{l}-0.049 \\
{[-1.33]}\end{array}$ & $\begin{array}{c}-0.258^{* * *} \\
{[-7.13]}\end{array}$ & $\begin{array}{c}0.054 * * * \\
{[2.71]}\end{array}$ & $\begin{array}{l}-0.052^{*} \\
{[-1.87]}\end{array}$ \\
\hline Expected default frequency $(E D F)$ & $\begin{array}{l}-0.084 \\
{[-0.74]}\end{array}$ & $\begin{array}{c}0.270 * * * \\
{[2.52]}\end{array}$ & $\begin{array}{l}-0.048 \\
{[-0.93]}\end{array}$ & $\begin{array}{c}0.502 * * * \\
{[6.90]}\end{array}$ \\
\hline Loan amount ( $\$$ million) & $\begin{array}{c}0.000 \\
{[-0.39]}\end{array}$ & $\begin{array}{c}-0.002^{* * * *} \\
{[-6.03]}\end{array}$ & $\begin{array}{c}0.001 * * * \\
{[5.25]}\end{array}$ & $\begin{array}{c}-0.001 * * * \\
{[-4.35]}\end{array}$ \\
\hline Loan maturity & $\begin{array}{c}0.000 \\
{[-0.15]}\end{array}$ & $\begin{array}{c}0.000 \\
{[-0.34]}\end{array}$ & $\begin{array}{c}0.002 * * * \\
{[2.58]}\end{array}$ & $\begin{array}{c}-0.003 * * * \\
{[-3.46]}\end{array}$ \\
\hline Collateral dummy & $\begin{array}{c}-0.208 * * * \\
{[-3.83]}\end{array}$ & $\begin{array}{c}0.343 * * * \\
{[5.01]}\end{array}$ & $\begin{array}{c}-0.217 * * * \\
{[-7.47]}\end{array}$ & $\begin{array}{c}0.288 * * * \\
{[4.84]}\end{array}$ \\
\hline Big 3 lender dummy & $\begin{array}{c}0.300 * * * \\
{[4.74]}\end{array}$ & $\begin{array}{l}-0.058 \\
{[-0.68]}\end{array}$ & $\begin{array}{c}0.101 * * * \\
{[3.34]}\end{array}$ & $\begin{array}{c}0.002 \\
{[0.05]}\end{array}$ \\
\hline Relationship-loan dummy & $\begin{array}{c}0.027 \\
{[0.74]}\end{array}$ & $\begin{array}{l}-0.059^{*} \\
{[-1.69]}\end{array}$ & $\begin{array}{l}-0.003 \\
{[-0.12]}\end{array}$ & $\begin{array}{c}-0.104 * * * \\
{[-3.48]}\end{array}$ \\
\hline Constant & $\begin{array}{l}-0.888 \\
{[-0.89]}\end{array}$ & $\begin{array}{c}7.015 * * * \\
{[8.98]}\end{array}$ & $\begin{array}{l}0.598 \\
{[0.54]}\end{array}$ & $\begin{array}{c}6.458^{* * * *} \\
{[6.93]}\end{array}$ \\
\hline Industry \& year fixed effects & Yes & Yes & Yes & Yes \\
\hline Loan types and purposes dummies & Yes & Yes & Yes & Yes \\
\hline$R^{2}$ & 0.42 & 0.64 & 0.166 & 0.236 \\
\hline $\mathrm{N}$ & 1535 & 1535 & 3923 & 3923 \\
\hline Weak-instrument test: & & & & \\
\hline First-stage F-stat & $\begin{array}{l}20.67 \\
{[0.00]}\end{array}$ & & $\begin{array}{c}5.27 \\
{[0.00]}\end{array}$ & \\
\hline $\begin{array}{l}\text { First-stage partial } R^{2} \\
\text { Endogeneity test: }\end{array}$ & $1.45 \%$ & & $1.50 \%$ & \\
\hline Durbin $\chi^{2}$ & $\begin{array}{l}14.23 \\
{[0.00]}\end{array}$ & & $\begin{array}{l}68.55 \\
{[0.00]}\end{array}$ & \\
\hline Wu-Hausman F-stat & $\begin{array}{c}13.29 \\
{[0.00]}\end{array}$ & & $\begin{array}{l}67.59 \\
{[0.00]}\end{array}$ & \\
\hline
\end{tabular}




\section{Table 10: Supply chain power and non-price loan contract terms}

This table reports coefficients from simultaneous regression estimates of price (loan spread) and non-price (maturity and collateral) loan contract terms. The definitions of all firm- and loan-level variables are given in Table A in the Appendix. t-statistics (with standard errors clustered at the firm and deal level) are given in parentheses. ( $* * *$ ' ' $* *$ ' , and ' $*$ ' denote significance at the $1 \%, 5 \%$, and $10 \%$ level, respectively.

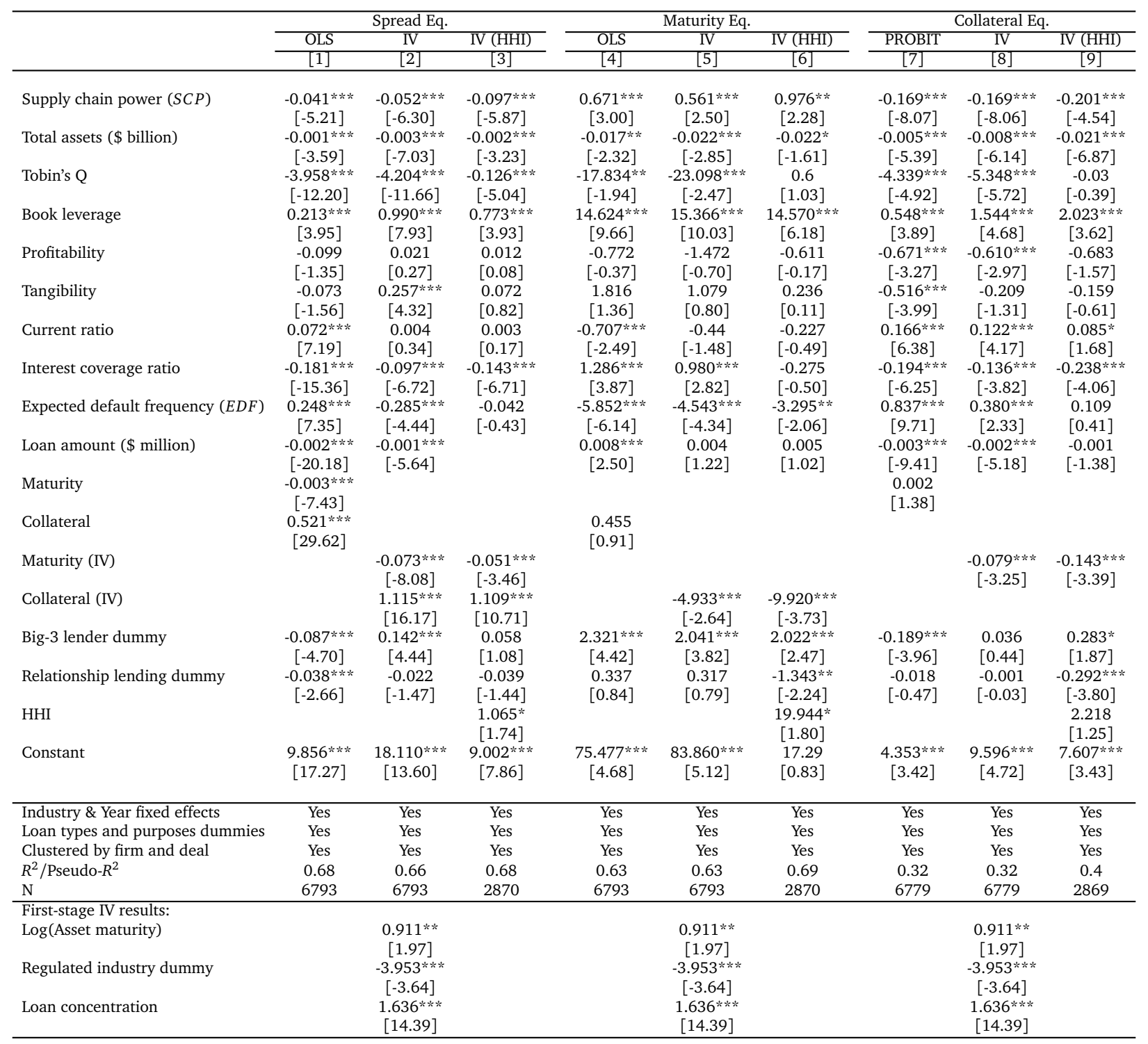




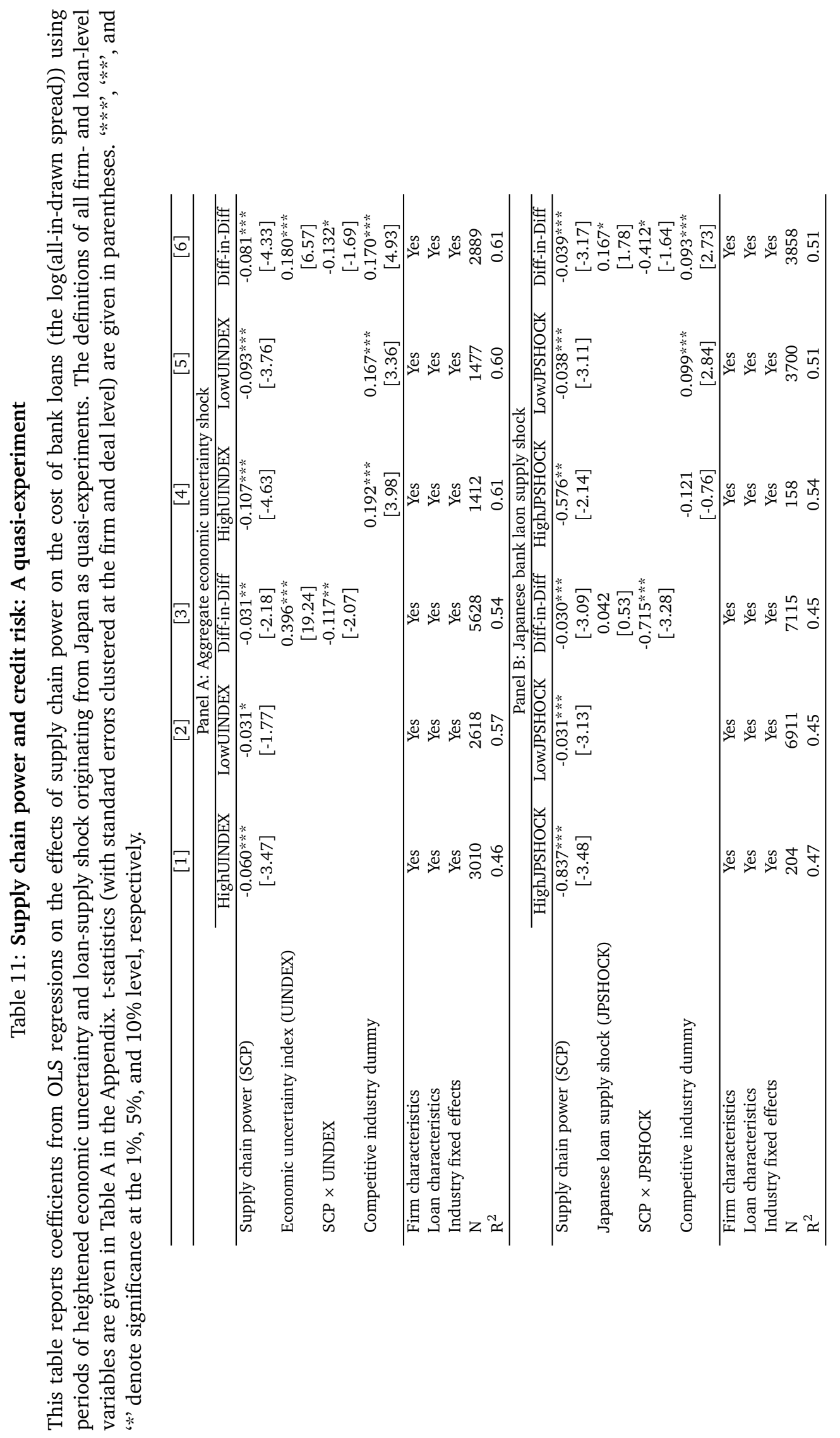




\section{Table 12: Supply chain hold-up risk and loan spread}

This table reports the effects of supply-chain power on the cost of bank debt in the presence of supply-chain hold-up risk. We follow Kim and Kung (2016) and Kim (2018) to construct the measure of firm-level asset specificity. We define a supply chain as more susceptible to hold-up risk if both the suppliers and the customer are in the top quartile of their respective asset specificity measure. Alternatively, we define a supply chain as less susceptible to hold-up risk if both the suppliers and the customer are in the bottom quartile of their respective asset specificity measures. Robust $t$ statistics are given in brackets; ' $*$ ' denotes significance at the $10 \%$ level; '**' denotes significance at the $5 \%$ level; and $* * *$ ' denotes significance at the $1 \%$ level.

\begin{tabular}{|c|c|c|c|c|c|c|c|}
\hline & {$[1]$} & [2] & [3] & [4] & [5] & [6] & [7] \\
\hline & $\begin{array}{c}\text { All } \\
\text { firms }\end{array}$ & $\begin{array}{l}\text { HIGH-SCP } \\
\text { firms }\end{array}$ & $\begin{array}{l}\text { LOW-SCP } \\
\text { firms }\end{array}$ & $\begin{array}{c}(2) \times(3) \\
\text { interaction }\end{array}$ & $\begin{array}{c}\text { HOLDUP } \\
\text { firms }\end{array}$ & $\begin{array}{l}\text { No-HOLDUP } \\
\text { firms }\end{array}$ & $\begin{array}{l}(5) \times(6) \\
\text { interaction }\end{array}$ \\
\hline HOLDUP & $\begin{array}{c}0.149 * * * \\
{[2.67]}\end{array}$ & $\begin{array}{c}0.087 \\
{[0.62]}\end{array}$ & $\begin{array}{c}0.356 * * * * \\
{[3.31]}\end{array}$ & $\begin{array}{c}0.205^{* *} \\
{[2.28]}\end{array}$ & & & $\begin{array}{c}0.132 * * * * \\
{[2.37]}\end{array}$ \\
\hline SCP & & & & $\begin{array}{c}-0.013 \\
{[-0.46]}\end{array}$ & $\begin{array}{l}-0.005 \\
{[-0.17]}\end{array}$ & $\begin{array}{c}-0.136 * * \\
{[-2.07]}\end{array}$ & $\begin{array}{c}-0.211 * * * \\
{[-3.09]}\end{array}$ \\
\hline SCP $\times$ HOLDUP & & & & $\begin{array}{c}-0.169 * * \\
{[-2.11]}\end{array}$ & & & \\
\hline HOLDUP $\times$ HIGHSCP & & & & & & & $\begin{array}{c}0.195^{*} \cdots * \\
{[2.66]}\end{array}$ \\
\hline Constant & $\begin{array}{c}8.536 * * * * \\
{[7.74]}\end{array}$ & $\begin{array}{c}6.883 * \cdots * * \\
{[4.37]}\end{array}$ & $\begin{array}{c}6.554 * * * * \\
{[5.99]}\end{array}$ & $\begin{array}{c}7.491 * \cdots * * \\
{[6.37]}\end{array}$ & $\begin{array}{c}7.140 * * * \\
{[5.97]}\end{array}$ & $\begin{array}{c}8.739 * * * * \\
{[8.33]}\end{array}$ & $\begin{array}{c}7.447 * * * \\
{[6.34]}\end{array}$ \\
\hline Firm-level controls & Yes & Yes & Yes & Yes & Yes & Yes & Yes \\
\hline Loan-level controls & Yes & Yes & Yes & Yes & Yes & Yes & Yes \\
\hline Industry-fixed effects & Yes & Yes & Yes & Yes & Yes & Yes & Yes \\
\hline $\mathrm{N}$ & 1135 & 240 & 379 & 619 & 675 & 460 & 1135 \\
\hline $\mathrm{R}^{2}$ & 0.62 & 0.70 & 0.74 & 0.66 & 0.57 & 0.76 & 0.62 \\
\hline
\end{tabular}




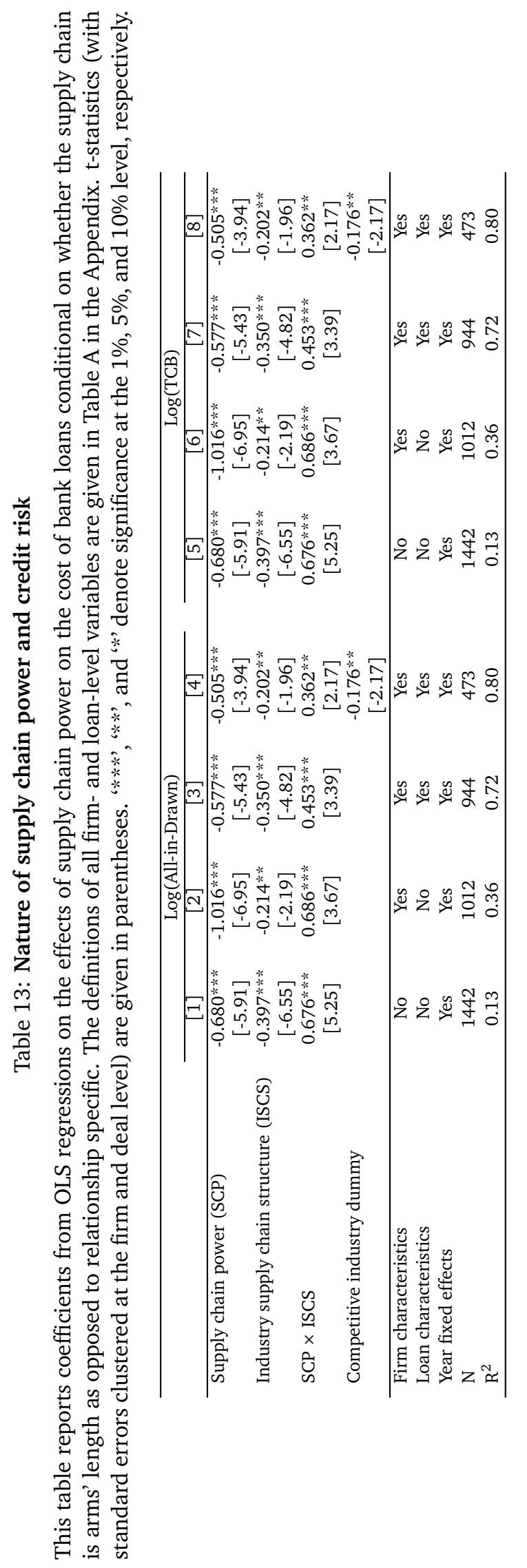


Table 14: Supply chain power and bankruptcy risk

This table reports coefficients from OLS regressions on the effects of supply chain power on various traditional measures of bankruptcy risk. Panel A of the table shows the correlation between loan spread and bankruptcy risk measures. Panel B shows the conditional OLS estimates of the effects of SCP on the likelihood of bankruptcy. The definitions of all firm- and loan-level variables are given in Table A in the Appendix. t-statistics (with standard errors clustered at the firm and deal level) are given in parentheses. ' $* * \cdots$, ' $* *$ ', and ' $*$ ' denote significance at the $1 \%, 5 \%$, and $10 \%$ level, respectively.

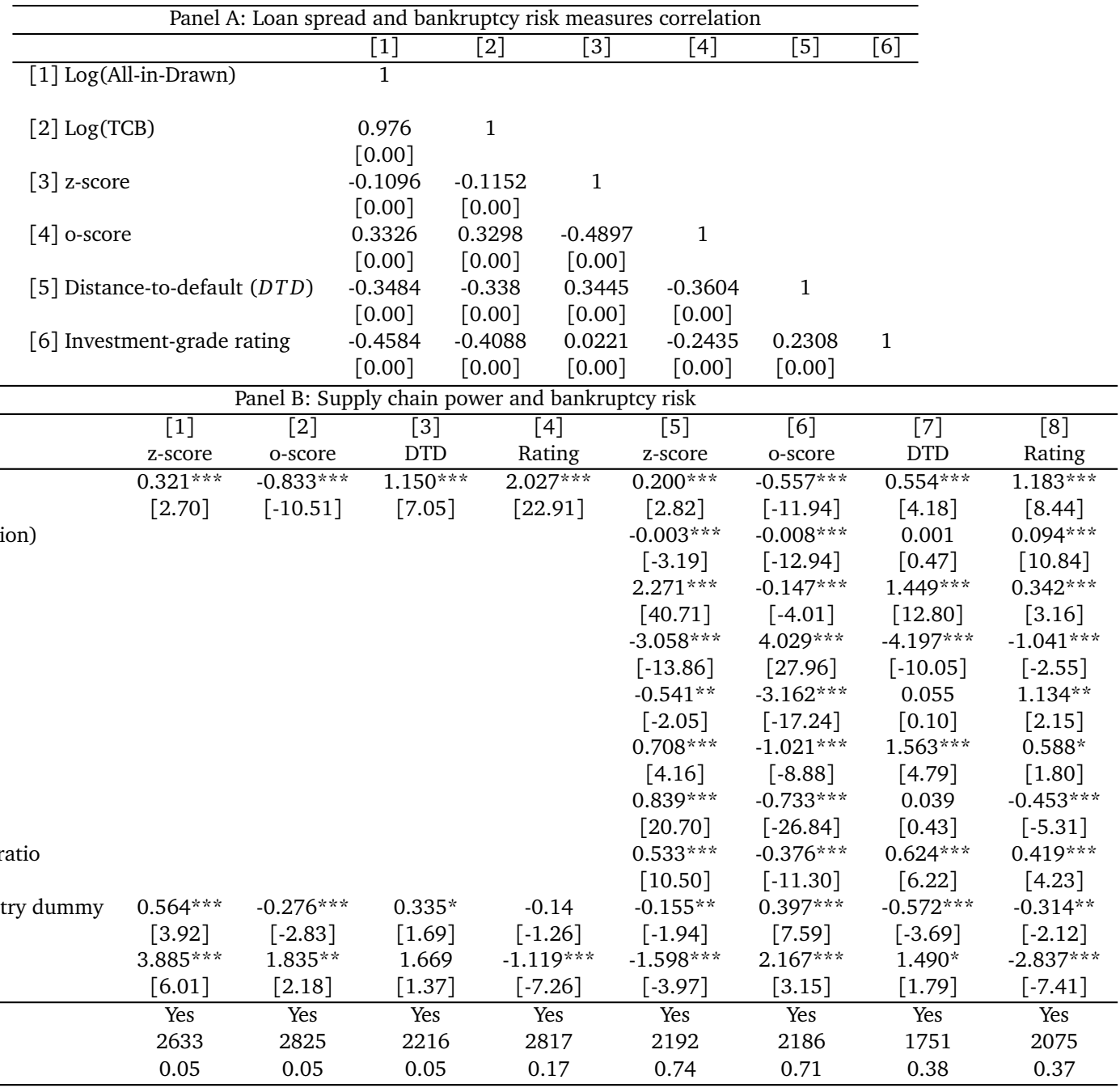




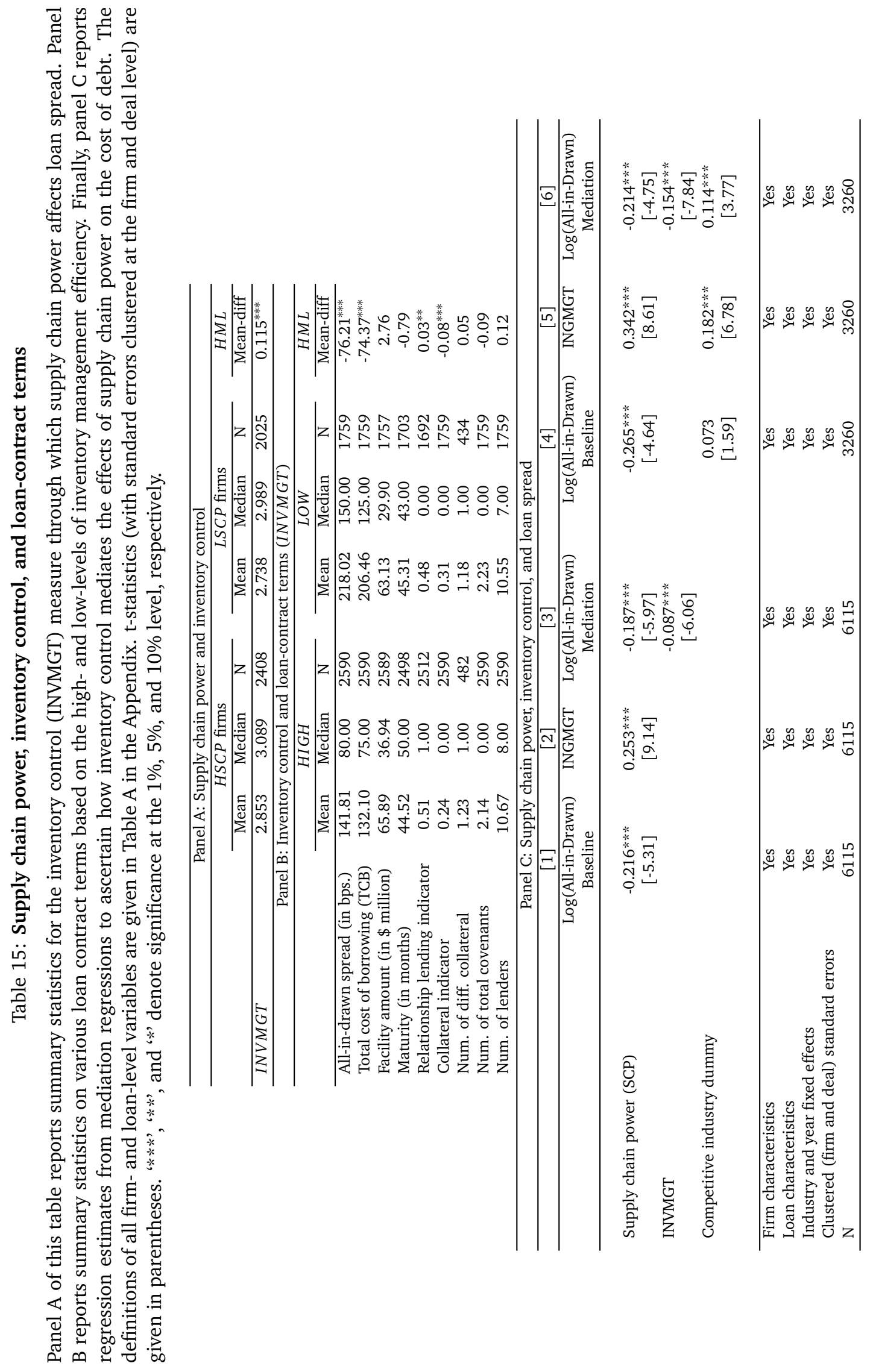


Table A: Definitions of Variables

\begin{tabular}{|c|c|}
\hline Variables & Definitions \\
\hline \multicolumn{2}{|l|}{ Firm Characteristics: } \\
\hline Firm size & Total book assets (in \$ billions); Compustat data item: at. \\
\hline Tobin's Q & $\begin{array}{l}\text { (Market value of equity plus the book value of debt)/Total assets; Compustat data items: }(a t-c e q+p r c c \times \\
c s h o) / a t \text {. }\end{array}$ \\
\hline Book leverage & (Long-term Debt + Debt in current liabilities)/Total assets; Compustat data items: $(d l t t+d l c) / a t$ \\
\hline Profitability & EBITDA/Total assets; Compustat data items: oibdp/at. \\
\hline Asset tangibility & Net Property, plant and equipment/Total assets; Compustat data items: ppent/at. \\
\hline Current ratio & Current assets/Current liabilities; Compustat data items: act/lct. \\
\hline Interest coverage ratio & EBITDA/Interest expenses; Compustat data items: oibdp/xint. \\
\hline Expected default frequency $(E D F)$ & $E D F$ is calculated following Bharath and Shumway's (2008) naive $E D F$ estimation procedure. \\
\hline S\&P credit rating dummy & Dummy variable indicating 1 if the firm has long-term S\&P credit rating. \\
\hline \multicolumn{2}{|l|}{ Loan Characteristics: } \\
\hline Log (Spread) & $\begin{array}{l}\text { Log(AIS Drawn over LIBOR); All-in-Drawn is the spread charged by the bank over LIBOR for the drawn } \\
\text { portion of the loan facility obtained from the LPC database. }\end{array}$ \\
\hline $\log (\mathrm{TCB})$ & Log(Total cost of borrowing); the TCB is defined following Berg, Saunders, and Steffen (2013). \\
\hline Facility amount & Loan facility amount (in \$ millions) obtained from the LPC database. \\
\hline Maturity & The maturity period (in months) of the bank loan obtained from the LPC database. \\
\hline Security type dummy & $\begin{array}{l}\text { One dummy variable for each collateral type. For firms with missing collateral information in DealScan, we } \\
\text { classify them into one group and use a dummy variable to indicate those firms. }\end{array}$ \\
\hline Security dummy & $\begin{array}{l}\text { Dummy variable that takes on the value of one if the loan facility is secured with collateral, and zero } \\
\text { otherwise. For firms with missing collateral information in DealScan, we replace the dummy variable with } \\
\text { zero. }\end{array}$ \\
\hline Number of covenants & Total number of covenants in a loan. \\
\hline Number of general covenants & $\begin{array}{l}\text { Total number of general covenants in a loan. General covenants are restrictions on prepayment, dividend, } \\
\text { and voting rights. Prepayment covenants usually specify that a loan must be repaid from a specific source } \\
\text { such as equity issuance, excess cash flow, excess asset sales, excess debt issuance, or insurance proceeds } \\
\text { related to the collateral. The dividend covenant limits the payment of dividends. The covenants on vot- } \\
\text { ing rights mandate the percentage of lenders required to approve the changes of the items in the loan } \\
\text { agreement, such as term changes and collateral release. }\end{array}$ \\
\hline Number of financial covenants & $\begin{array}{l}\text { Total number of financial covenants in a loan. It counts the number of limits placed on the level of different } \\
\text { accounting variables or ratios that must be maintained while the debt is outstanding. }\end{array}$ \\
\hline Number of lenders & Total number of lenders in a loan contract. \\
\hline Big-3 lenders & $\begin{array}{l}\text { A dummy variable indicating whether the lead bank is any of the three major U.S. banks, i.e., the Bank of } \\
\text { America, Citigroup, and J.P. Morgan Chase. }\end{array}$ \\
\hline Loan-type dummy & $\begin{array}{l}\text { Dummy variable indicating loan types such as term loan, revolver greater than one year, revolver less than } \\
\text { one year, and 364-day facility. }\end{array}$ \\
\hline Loan-purpose dummy & Dummy Variable for each loan purpose, including Debt repayment, Corporate purpose, and Working capital. \\
\hline \multicolumn{2}{|l|}{ Other Independent Variables: } \\
\hline ISCS & $\begin{array}{l}\text { The industry-level supply-chain specificity measure. The measure is constructed based on Nunn (2007). It } \\
\text { measures the fraction of intermediary inputs (or broadly defined as assets) used in the production of the } \\
\text { final six-digit NAICS product that is either sold in an organized market or reference priced. In other words, } \\
\text { it captures the extent to which a firm may need to rely on arm's-length as opposed to relationship-specific } \\
\text { supply chain in any given industry. }\end{array}$ \\
\hline$S C P$ & $\begin{array}{l}\text { The firm-level supply chain power measure. The measure is constructed based on the first Principal Com- } \\
\text { ponent of three firm-level variables related to the firm's supply chain: (i) Log(1+Number suppliers), which } \\
\text { captures the thickness of the supply chain; (ii) input-based Herfindahl index, which captures the dispersion } \\
\text { among suppliers; and (iii) input-weighted Lerner's index, which captures a firm's market power over its } \\
\text { suppliers. }\end{array}$ \\
\hline UINDEX & $\begin{array}{l}\text { The uncertainty index is from Baker, Bloom, and Davis (2016). The index is based on the following se- } \\
\text { ries: (i) monthly news articles containing 'uncertain' or 'uncertainty', 'economic' or 'economy', and policy- } \\
\text { relevant terms (scaled by the smoothed number of articles containing 'today'); (ii) the number of tax laws } \\
\text { expiring in coming years; (iii) the interquartile ranges for quarterly forecasts of federal government ex- } \\
\text { penditures from the Philadelphia Fed Survey of Forecasters; (iv) a composite of interquartile ranges for } \\
\text { quarterly forecasts of 1-year CPI from the Philadelphia Fed Survey of Forecasters. }\end{array}$ \\
\hline$H H I$ & $\begin{array}{l}\text { A sales-based Herfindahl index to measure industry concentration. Following Valta (2012), we use the fitted } \\
\text { Herfindahl-Hirschman Index (HHI) of Hoberg and Phillips (2016) to capture product-market competition. } \\
\text { A higher value of the index indicates a concentrated with a few dominant players. }\end{array}$ \\
\hline CUSTCON & $\begin{array}{l}\text { This is another measure of product-market competition based on the customer concentration measure of } \\
\text { Patatoukas (2012). }\end{array}$ \\
\hline$I N V M G T$ & $\begin{array}{l}\text { A measure of inventory management efficiency captured by the signal-to-noise ratio of inventory, where } \\
\text { signal is the average level of inventory in the last three years and noise is the volatility (standard deviation) } \\
\text { of inventory over the last three years. The measure is calculated using the quarterly Compustat data. }\end{array}$ \\
\hline
\end{tabular}

